\title{
Paired Pulse Depression in Cultured Hippocampal Neurons Is Due to a Presynaptic Mechanism Independent of GABA Autoreceptor $_{B}$ Activation
}

\author{
Karen S. Wilcox ${ }^{1, a}$ and Marc A. Dichter ${ }^{2}$ \\ 1Department of Physiology and '2Departments of Neurology and Pharmacology, University of Pennsylvania, School of \\ Medicine, and Graduate Hospital, Philadelphia, PA 19104
}

\begin{abstract}
Most rapid synaptic inhibition in the vertebrate forebrain is mediated by GABA acting via $\mathrm{GABA}_{A}$ and $\mathrm{GABA}_{B}$ postsynaptic receptors. GABAergic neurotransmission exhibits frequency-dependent modulation; sequential inhibitory postsynaptic currents (IPSCs) evoked with interstimulus intervals between $25 \mathrm{msec}$ and $4 \mathrm{sec}$ routinely result in the attenuation of the amplitude of the second IPSC. This form of synaptic plasticity is known as paired pulse depression (PPD). The mechanism of PPD is presently unknown and the experiments performed in this study were designed to determine directly the location of the mechanism of PPD in hippocampal neurons maintained in low-density tissue culture. Evoked IPSCs were recorded between pairs of cultured neurons grown in relative isolation that were simultaneously being recorded with the whole-cell, patch-clamp technique. It was therefore possible to measure miniature IPSCs (mIPSCs) originating from the same synapses that were being stimulated to evoke release. PPD occurred routinely in this system, but the amplitudes of mIPSCs following IPSCs were unchanged. These results indicate that a presynaptic mechanism mediates PPD. The inability of $\mathrm{GABA}_{\mathrm{B}}$ receptor antagonists to block PPD revealed that this form of presynaptic plasticity was not due to autoinhibition of transmitter release via activation of presynaptic GABA $\mathrm{A}_{B}$ receptors. However, manipulations that significantly lowered the probability of release of neurotransmitter during the first action potential of a trial (e.g., lower calcium or baclofen) prevented the development of PPD. These results indicate that, under baseline conditions, the quantal content for IPSCs is relatively large for a single action potential, but the quantal content rapidly decreases, such that subsequent action potentials consistently result in much smaller IPSCs for periods as long as 4 sec.
\end{abstract}

[Key words: IPSC, miniature IPSC, paired pulse depression, tissue culture, patch clamp, GABA]

Received Apr. 27, 1993; revised Sept. 2. 1993; accepted Sept. 13, 1993.

We thank Drs. Donald Faber and Michael Selzer for critical review of an earlier version of the manuscript, Dr. Jeff Buchhalter for help in the development of the culture system, and Ms. Kay Cherian for preparation and maintenance of the tissue cultures. This work was supported by NS24260 (M.A.D.)

Correspondence should be addressed to Marc A. Dichter, M.D., Ph.D., Department of Neurology, Graduate Hospital, 19th and Lombard Streets, Philadelphia, PA 19146.

a Present address: Department of Neurology, School of Medicine, University of Pennsylvania, Philadelphia, PA 19104.

Copyright (C) 1994 Society for Neuroscience $0270-6474 / 94 / 141775-14 \$ 05.00 / 0$
Under physiological conditions, synaptic inhibition in the mammalian CNS is very labile and a downregulation of inhibitory neurotransmission appears to be critical for the development of some forms of synaptic plasticity, such as that occurring during long-term potentiation. In addition, and perhaps even more significantly, activity-dependent disinhibition is also associated with the generation and spread of epileptic seizure activity (Dichter and Ayala, 1987). Therefore, an understanding of the basic principles of inhibitory plasticity is vital to the understanding of both physiological and pathological synaptic plasticity in the CNS.

Paired pulse depression (PPD) of GABAergic inhibitory postsynaptic currents (IPSCs) is a robust example of synaptic plasticity in the mammalian CNS; depression of the amplitude of a second IPSC can be seen for up to $4 \mathrm{sec}$ following a single stimulus (Deisz and Prince, 1989; Davies et al., 1990; Yoon and Rothman, 1991; Mott et al., 1993). The mechanism underlying such PPD at inhibitory synapses in the CNS is currently unknown, although several presynaptic and postsynaptic mechanisms have been hypothesized to play a role in a similar form of disinhibition that occurs as a result of trains of presynaptic stimulation. Postsynaptic mechanisms that could explain the decrease in inhibition following rapid repetitive stimulation, and, by analogy, the decrease seen in PPD, include (1) a decrease in the driving force due to intracellular accumulation of $\mathrm{Cl}^{-}$and extracellular accumulation of $\mathrm{K}^{+}$(McCarren and Alger, 1985; Thompson and Gahwiler, 1989a,b), (2) a desensitization of the $\mathrm{GABA}_{\mathrm{A}}$ receptor (Ben-Ari et al., 1979; Alger, 1991), and (3) modulation of the conductance of the $\mathrm{GABA}_{\mathrm{A}}$ receptor due to the co-release of various neuroactive modulators such as somatostatin, a peptide that has been shown to decrease the postsynaptic response to evoked release of GABA (Delfs and Dichter, 1983; Scharfman and Schwartzkroin, 1989).

There are at least two presynaptic mechanisms that could mediate the decrease in current amplitude seen during PPD. The first hypothesis suggests that the decreased amplitude of the second IPSC occurs due to a transient decrease in the quantal content $(m)$ of released neurotransmitter (Korn et al., 1984). This decrease in $m$ could be due to a wide variety of mechanisms, such as a lack of available neurotransmitter vesicles that are biochemically prepared to be secreted (Greengard et al., 1993), or a decrease in the number of "empty" active zones to which vesicles can fuse and subsequently secrete neurotransmitters into the synaptic cleft, or a decrease in the probability of release for available vesicles of neurotransmitter. Presently, the most widely accepted hypothesis for the decreased ampli- 
tude of IPSCs following both repctitive and paircd stimulation is a presynaptic mechanism that is the result of autoinhibition of GABA release due to the activation of presynaptic $\mathrm{GABA}_{\mathrm{B}}$ receptors (Deisz and Prince, 1989; Davies et al., 1990, 1991; Otis and Mody, 1992; Mott et al., 1993). The autoinhibition of subsequent GABA release would then occur as a result of one of two possible mechanisms through which $\mathrm{GABA}_{\mathrm{B}}$ receptors are thought to work: (1) $\mathrm{GABA}_{\mathrm{B}}$ activation would decrease calcium currents at the terminal and therefore decrease the amount of neurotransmitter released via $\mathrm{Ca}^{2+}$-dependent neurotransmitter release (Dolphin and Scott, 1987; Scholz and Miller, 1991), or (2) GABA $_{B}$ activation would cause a G-protein-linked increase in a potassium conductance that would hyperpolarize the terminal (Gahwiler and Brown, 1985; Bormann, 1988).

The goal of the work described here has been to perform experiments that directly determine the location of the mechanism underlying simple frequency-dependent decreases in inhibitory neurotransmission. In order to determine if the mechanism underlying PPD is located at a presynaptic or postsynaptic location, the whole-cell, patch-clamp technique was used to evoke monosynaptic IPSCs between isolated pairs of hippocampal neurons in very low-density cultures. Very few preparations of the mammalian CNS allow for the routine electrophysiological recording between monosynaptically connected pairs of neurons in the absence of polysynaptic circuits. However, in the low-density cultures, it is possible to patch clamp both the presynaptic and postsynaptic neuron of a pair and therefore have direct control over the firing patterns of the presynaptic cell, as well as the holding potential of the postsynaptic cell. In addition, because only two cells are involved in the circuit, it is possible to monitor the miniature IPSCs (mIPSCs) that spontaneously occur in an action potential independent manner at a majority of the same synaptic terminals that produce the evoked IPSCs. Analysis of the mIPSCs thus provide a direct measure of $q$, the quantal amplitude (del Castillo and Katz, 1954; Van Der Kloot, 1991; Malgaroli and Tsien, 1992; Manabe et al., 1992; Otis and Mody, 1992). This experimental paradigm greatly facilitates the analysis of various forms of frequency-dependent synaptic plasticity, and provides a mechanism through which direct tests of presynaptic and postsynaptic contributions to changes in synaptic efficacy can be monitored (Redman, 1990; Korn and Faber, 1991).

In the experiments described here, monosynaptically evoked IPSCs between pairs of hippocampal neurons in low-density cultures were characterized, and found to be mediated exclusively by the activation of postsynaptic $\mathrm{GABA}_{\mathrm{A}}$ receptors. The amplitudes of the IPSCs were quite sensitive to the frequency with which the presynaptic cell fired action potentials. Robust PPD was found to occur routinely between monosynaptically connected neurons in our model system. However, the amplitudes of mIPSCs immediately following evoked IPSCs were unchanged, directly indicating a presynaptic location of the mechanism responsible for PPD (del Castillo and Katz, 1954; Van Der Kloot, 1991; Malgaroli and Tsien, 1992; Manabe et al., 1992; Otis and Mody, 1992). Moreover, the inability of $\mathrm{GABA}_{\mathrm{B}}$ receptor antagonists to block PPD demonstrated that this form of presynaptic plasticity was not due to autoinhibition of transmitter release via activation of presynaptic $\mathrm{GABA}_{B}$ receptors, as has been suggested (Deisz and Prince, 1989; Thompson and Gahwiler, 1989c; Davies et al., 1990; Otis and Mody, 1992; Mott et al., 1993). Additional experiments demonstrated that it was possible to prevent PPD in this simple model system by recording in conditions that decreased the probability of release of neurotransmitter during the first action potential.

\section{Materials and Methods}

Tissue culture. Primary dissociated cultures were prepared from embryonic rat hippocampi as previously described, although some modifications of the method were incorporated (Buchhalter and Dichter, 1991). Pregnant Sprague-Dawley rats were narcotized with $\mathrm{CO}_{2}$ and killed by cervical dislocation. The embryos, gestational day $18-20$, were removed, the brains rapidly extracted and hippocampi dissected under microscopic visualization. The hippocampi were incubated for $40 \mathrm{~min}$ in a 10\% Dulbecco's Minimum Essential Medium (DMEM) solution containing $0.027 \%$ trypsin at $37^{\circ} \mathrm{C}$. The hippocampi were then thoroughly washed in HEPES-buffered saline (HBS) and placed in a medium containing DMEM, supplemented with 10\% Hyclone calf serum, $10 \%$ Ham's F1 2 containing glutamine, and $50 \mathrm{U} / \mathrm{ml}$ penicillin-streptomycin (Sigma). The cells were triturated with a Pasteur pipette, and plated onto poly-L-lysine (Peninsula Labs)-coated glass coverslips in $35 \mathrm{~mm}$ petri dishes at concentrations ranging from 35,000 to 150,000 viable neurons per milliliter. Some cultures were plated directly onto poly-Llysine-coated plastic petri dishes $(35 \mathrm{~mm})$. The cultures were maintained in a humidified incubator at $37^{\circ} \mathrm{C}$ with $7 \% \mathrm{CO}_{2}$. After $1-5 \mathrm{~d}$, the medium was partially replaced with one containing a high external potassium concentration $(20 \mathrm{~mm})$ to enhance survival and the petri dishes were placed in a closed, humidified container in the incubator to prevent evaporation. Cultures were fed once a week with one or two drops of the high $\left[\mathrm{K}^{+}\right]$o medium (Mattson and Kater, 1989). In some cases, neurons were plated on a confluent layer of embryonic glia obtained from rat cerebral cortex. In these cases, the medium was not replaced with one containing high $\left[\mathrm{K}^{+}\right]_{o}$ and the culture was fed three times a week hy replacing $0.5 \mathrm{ml}$ of medium with fresh medium. There were no detectable differences in the low-density cultures of neurons grown under this condition.

Electrophysiological recordings. Membrane currents were recorded at room temperature using the whole-cell variant of the patch-clamp technique from neurons maintained in culture for 14-30 d (Hamill et al., 1981). Isolated pairs of neurons were visualized using phase-contrast microscopy with a Nikon inverted microscope. Low-impedance electrodes $(2-6 \mathrm{M} \Omega$ ) were fashioned from borosilicate glass capillaries (Ki$\max$ ). Cell-attached $G \Omega$ seals were obtained on both neurons of a selected pair, prior to applying gentle suction to break the membrane to attain the whole-cell mode. The presynaptic neuron was monitored in the current-clamp mode, and recorded with a DAGAN 3900 amplifier. The postsynaptic neuron was recorded in the voltage-clamp mode with a DAGAN 8900 amplifier equipped with a reference electrode. Leak resistance of the postsynaptic neuron was periodically checked during the course of the experiments and ranged from $\sim 300 \mathrm{M} \Omega$ to $1.0 \mathrm{G} \Omega$. Electrode offset potentials were compensated prior to recording with amplifier circuitry. The bath was perfused continuously at a rate of approximately $1 \mathrm{ml} / \mathrm{min}$. Data were stored on videotape and later digitized at $2-10 \mathrm{kHz}$ and analyzed with either a PDP $11 / 73$ computer system or pCLAMP software (Axon Instruments).

Recording solutions. The bath solution, an HBS solution, contained (in mM) $\mathrm{NaCl}, 140$; KCl, 3; HEPES-NaOH buffer, 10; glucose, 10; and $\mathrm{CaCl}, 4$. In some experiments glycine $(10 \mu \mathrm{M})$ was included so that nonrelated experiments with excitatory postsynaptic currents (EPSCs) could be performed. Some preliminary experiments were performed with $\left[\mathrm{Ca}^{++}\right]=2 \mathrm{mM}$ and $\left[\mathrm{Mg}^{2+}\right]=1 \mathrm{~mm}$, and PPD was unaffected. Internal pipette recording solutions contained (in $\mathrm{mm}$ ) potassium gluconate (K-gluconate) $(120)$ and $\mathrm{KCl}(10)$, or in some experiments $\mathrm{KCl}$ (140) in the postsynaptic neuron, HEPES (10), EGTA (1), $\mathrm{CaCl}_{2}$ (1), ATP- $\mathrm{Mg}^{2+}(2.5)$, and glucose (10). The use of $\mathrm{KCl}$ electrodes in the postsynaptic cell increased the amplitudes of the mIPSCs at $-70 \mathrm{mV}$. The $\mathrm{pH}$ of both solutions was maintained at 7.3-7.4, and osmolarities for the external solution ranged from 295 to $305 \mathrm{mOsm}$ and from 285 to 295 mOsm for the internal solutions. In experiments where the concentration of calcium was changed, the divalent cation concentration was maintained at a constant level by adjusting the concentration of $\mathrm{Mg}^{2+}$ accordingly. Drugs were perfused into the bath with a peristaltic pump. Receptor antagonists and agonists used in this study included bicuculline methiodide (10 $\mu \mathrm{M})$, 6-cyano-7-nitroquinoxaline-2,3-dione (CNQX) $(10 \mu \mathrm{M})$, and 2-amino-5-phosphonovalerate (APV) $(100 \mu \mathrm{M})$ (all from Sigma); 2-OH-saclofen $(100 \mu \mathrm{M})$, phaclofen $(100 \mu \mathrm{M})$, and $( \pm)$ baclofen $(2 \mu \mathrm{M}$ and $10 \mu \mathrm{M})$ (all from Research Biochemicals Inc.); and CGP-35348 (a gift from CIBA GEIGY). 
A.

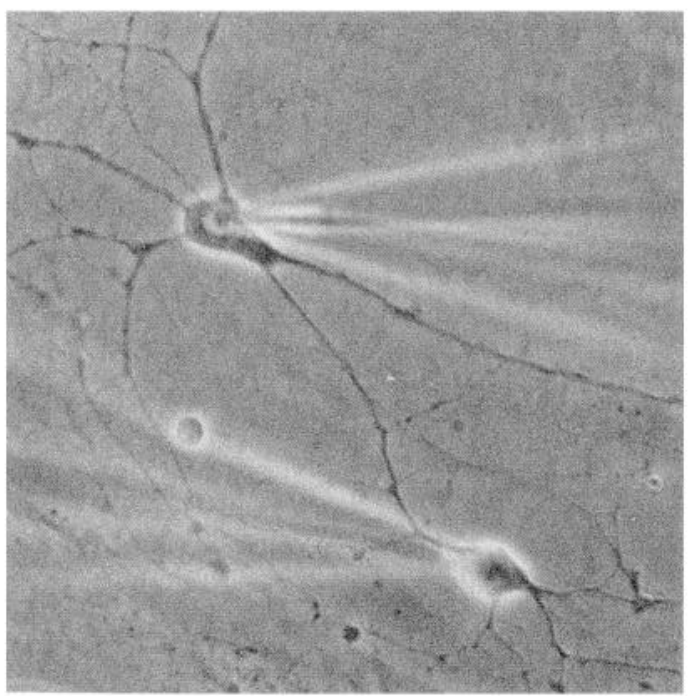

B.

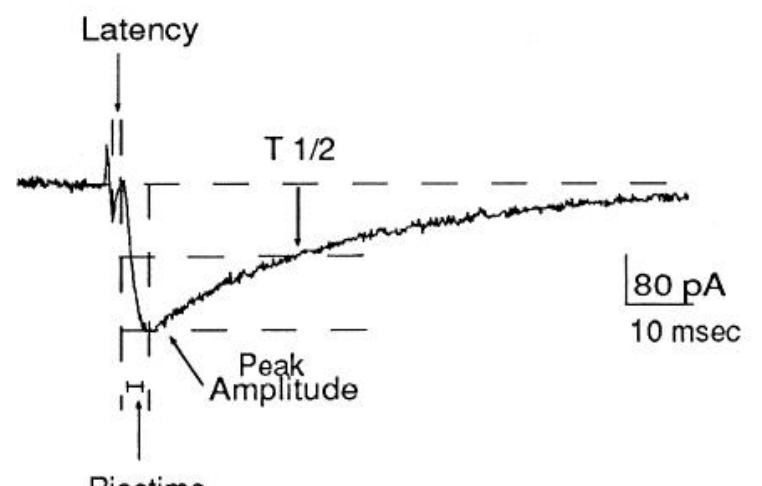

Risetime

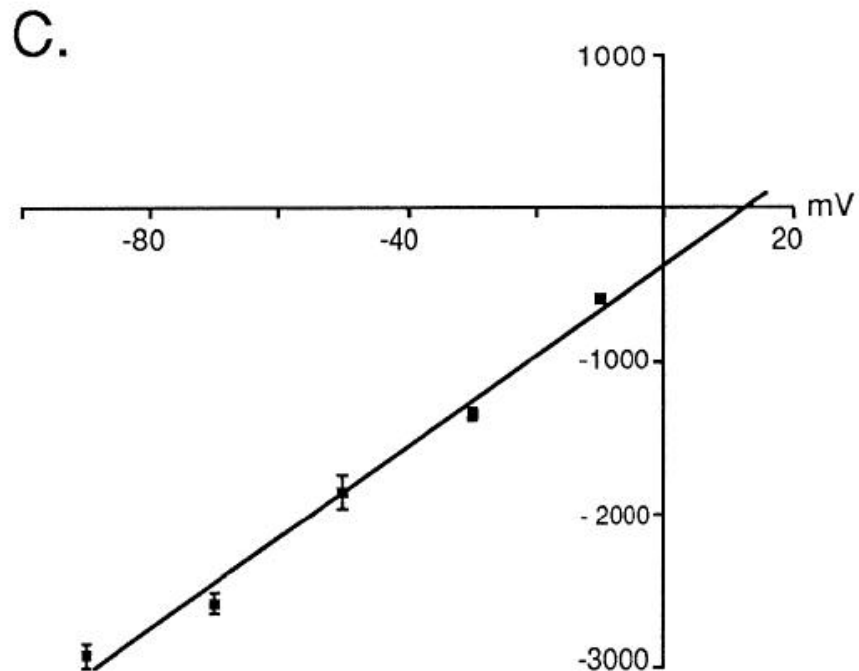

$-3000$

D.

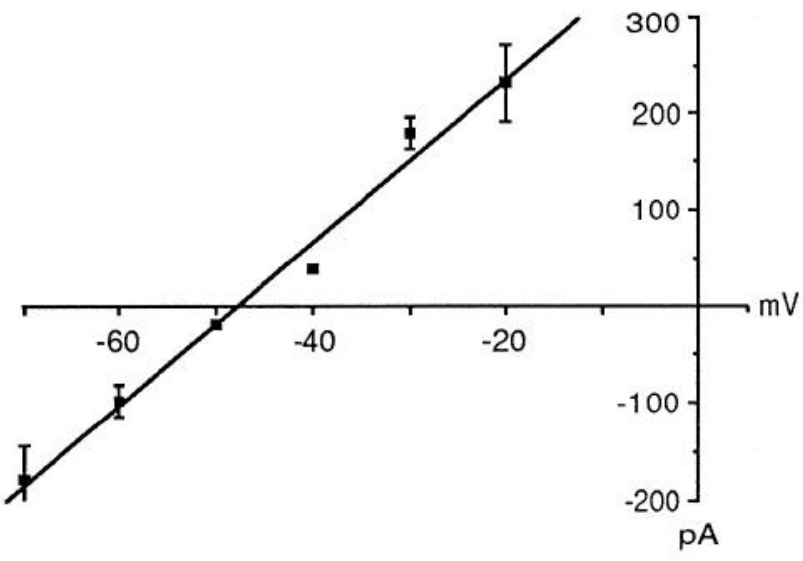

$\mathrm{pA}$

Figure 1. Pairs of cultured embryonic hippocampal neurons are frequently found in isolation in the low-density culture preparation. $A$, The neurons in this figure were simultaneously patch clamped (note presence of patch electrodes) for recording both evoked and miniature receptoractivated currents in a simple model of CNS neurons. $B$, Latency, rise time, peak amplitude, and the decay time to half-amplitude were measured for monosynaptically evoked PSCs between pairs of neurons. Currents were filtered at $10 \mathrm{kHz}$, and sampled at $100 \mu \mathrm{sec} / \mathrm{pt}$. An inhibitory postsynaptic current (IPSC) recorded using potassium gluconate as the predominant electrode constituent was recorded in response to a single presynaptic action potential. Currents are inward at a holding potential of $-70 \mathrm{mV}$. Latency was measured as the time from the second peak of the stimulus artifact (end of the action potential) to the point at which the IPSC began to fall from the baseline. Rise time was measured as the time from the point at which the IPSC began to deviate from the baseline to the peak amplitude. The decay time to one-half amplitude $(T 1 / 2)$ was measured as the point at which the IPSC departed from the baseline until the IPSC returned to one-half the maximum amplitude. This measure was chosen to define the duration of the PSCs as a double exponential was required to fit to the decay of the IPSC. Current-voltage relationships of the IPSCs in the presence of either $140 \mathrm{~mm} \mathrm{KCl}(C)$ or $120 \mathrm{~mm}$ potassium gluconate $(D)$ in the recording electrode. Reliable reversal potentials were somewhat difficult to achieve in the presence of $\mathrm{KCl}(140 \mathrm{~mm})$. At depolarized potentials, IPSCs were sometimes observed to elicit action currents in the postsynaptic membrane and, furthermore, the opening of voltage-sensitive ion channels would contribute to total charge transfer during the IPSC. Each point represents the mean $\pm \mathrm{SD}$ for at least five IPSCs at a given potential. The reversal potential was near $+10 \mathrm{mV}$ in $C$ and $-50 \mathrm{mV}$ in $D$.

Analysis. Postsynaptic currents (PSCs) were considered monosynaptic when they followed a presynaptic action potential with a relatively short and constant latency and did not show any evidence of failures following an action potential. The divalent cation concentration was usually maintained relatively high $(4.0 \mathrm{~mm})$ to reduce the excitability of the membrane, and therefore reduce the probability of spontaneous action po- tentials by both the presynaptic neuron and any neurons involved in the circuit. EPSCs and IPSCs were distinguished on the basis of reversal potential. With potassium gluconate electrodes, the reversal potential for the IPSCs was approximately $-50 \mathrm{mV}$, whereas the reversal potential for the EPSCs remained near $+10 \mathrm{mV}$.

Data were analyzed using semiautomated software that measured the 
Table 1. Properties of evoked IPSCs

\begin{tabular}{lllll} 
Cell & $\begin{array}{l}\text { Latency } \\
(\mathrm{msec})\end{array}$ & $\begin{array}{l}\text { Recay time } \\
(\mathrm{msec})\end{array}$ & $\begin{array}{l}\text { De } 1 / 2 \\
\text { amplitude } \\
(\mathrm{msec})\end{array}$ & $\begin{array}{l}\text { Peak current } \\
(\mathrm{pA})\end{array}$ \\
\hline $1(n=16)$ & $1.3 \pm 0.2$ & $3.6 \pm 0.3$ & $15.0 \pm 0.8$ & $-634 \pm 21$ \\
$2(n=14)$ & $2.0 \pm 0.4$ & $3.1 \pm 0.4$ & $17.5 \pm 0.8$ & $-781 \pm 59$ \\
$3(n=16)$ & $1.8 \pm 0.3$ & $2.6 \pm 0.3$ & $13.8 \pm 2.3$ & $-314 \pm 11$ \\
$4(n=16)$ & $1.9 \pm 0.4$ & $3.3 \pm 0.4$ & $19.9 \pm 2.0$ & $-128 \pm 5$ \\
$5(n=14)$ & $1.8 \pm 0.3$ & $2.2 \pm 0.3$ & $16.8 \pm 1.4$ & $-286 \pm 28$ \\
Mean $\pm \mathrm{SD}$ & $1.7 \pm 0.3$ & $2.9 \pm 0.6$ & $16.6 \pm 2.3$ & $-428 \pm 269$
\end{tabular}

The number of IPSCs evaluated for each cell is listed in parentheses next to the cell number. Measurements for each parameter (means \pm SD) were made as described in the Results. Values described in the bottom row (means \pm SD) were calculated based on the overall mean values for each individual cell, and therefore $n=5$ for this row.

latencies, rise times, amplitudes, and decay time to half-amplitude. The coefficient of variance $(\mathrm{CV})$ was determined by $\mathrm{CV}=$ standard deviation of the mean amplitude/mean amplitude.

Amplitudes for miniature currents were plotted on relative cumulative frequency histograms. This plots the cumulative frequency of all currents as a function of amplitude. Several populations of minis can then be simultaneously plotted on the same graph. The nonparametric test statistic, Kolmogorov-Smirnov, is then applied to various populations of minis to determine differences. Only values of $p<0.05$ were considered significant in this study (Van der Kloot, 1991).

\section{Results}

Monosynaptically connected pairs of neurons were routinely recorded in the low-density culture system (Fig. $1 \mathrm{~A}$ ). The presynaplic cells, in most cases, were recorded in the whole-cell, current-clamp mode, so that action potentials could be reliably elicited and monitored. The postsynaptic cells were voltage clamped at $-70 \mathrm{mV}$ or $-80 \mathrm{mV}$ and evoked PSCs were monitored. Occasionally, pairs of neurons had reciprocal synapses, although reciprocality was not looked for routinely. For most experiments, it was not necessary to include receptor antagonists in the bath to isolate EPSCs from IPSCs, as the internal solution used in the recording allowed for a distinction between the two types of currents based on the reversal potential. When potassium gluconate was used as the primary constituent of the intracellular solution, the IPSCs reversed near $-50 \mathrm{mV}$, whereas the EPSCs reversed near $+10 \mathrm{mV}$.

In total, 89 pairs of monosynaptically connected neurons were successfully recorded. Of those pairs, 65 were inhibitory pairs and 24 were excitatory pairs. Table 1 summarizes the basic properties of the IPSCs for five representative neurons recorded with potassium gluconate as the major intracellular constituent. Measurements of latency, rise time, the peak amplitude, and the decay time to half-amplitude were made for at least 14 PSCs for each cell examined in detail. Figure $1 B$ illustrates the way in which each measurement was made.

\section{Properties of IPSCS}

Presynaptic stimulation of action potentials resulted in postsynaptic, inward currents that occurred with a rapid and constant latency. For five cells examined in detail (see Table 1), the mean latency of the evoked response was $1.7 \pm 0.3 \mathrm{msec}$. The rise time from the baseline to the peak of the current was rapid, with a mean of $2.9 \pm 0.6 \mathrm{msec}(n=5 \mathrm{cells})$. An IPSC was never observed if the presynaptic cell failed to generate an action potential, and due to the high concentration of calcium used in
A.

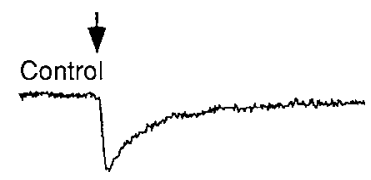

Bicuculline $(10 \mu \mathrm{M})$
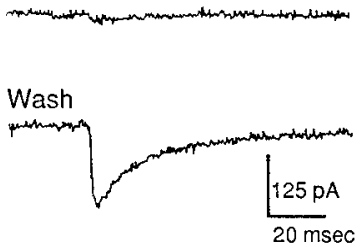

B.

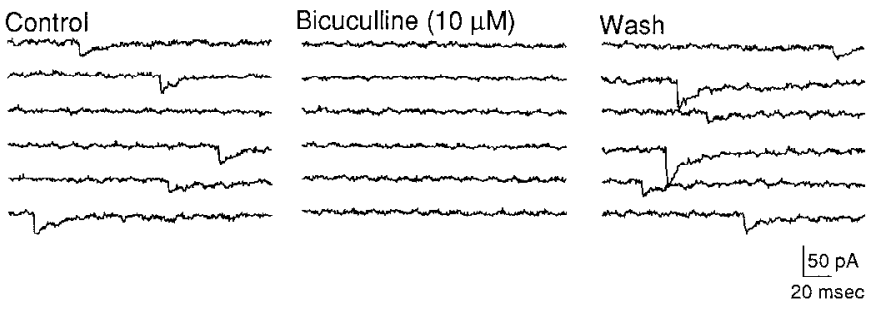

Figure 2. Bicuculline-sensitive IPSCs and mIPSCs. $A$, Perfusion of the selective $\mathrm{GABA}_{\mathrm{A}}$ receptor antagonist bicuculline $(10 \mu \mathrm{M})$ reversibly blocked the evoked IPSCs. There was no evidence for a slow, outward $\mathrm{GABA}_{\mathrm{B}}$-mediated IPSC in the presence of bicuculline, suggesting that only receptors for $\mathrm{GABA}_{\mathrm{A}}$ are present at the postsynaptic site. $B$, Examples of mIPSCs. The membrane potential was held at $-70 \mathrm{mV}$ and a high-chloride internal solution was used to increase the driving force. The standard bathing media for recording miniature currents contained TTX $(1 \mu \mathrm{M})$ to block action potentials, $2 \mathrm{mM} \mathrm{Mg}^{2+}$, and CNQX (10 $\mu \mathrm{M})$ and APV $(100 \mu \mathrm{M})$ to block excitatory amino acid receptors. Traces were filtered at $2 \mathrm{kHz}$. The currents had fast rise times, small amplitudes, and long decays that could be fit with a single exponential. As with evoked IPSCs, bicuculline methiodide $(10 \mu \mathrm{M})$ completely and reversibly blocks the spontaneous miniature currents.

these experiments (2-4 mM), failures following an action potential were not observed.

With potassium gluconate in the electrode, the reversal potential of these currents was approximately $-50 \mathrm{mV}$. When $\mathrm{KCl}$ was the predominant component of the intracellular solution, the reversal potential remained near $+10 \mathrm{mV}$ (Fig. 1C), which was similar to the reversal potential for EPSCs in this culture system. Therefore, to ensure that all PSCs were inhibitory, the excitatory amino acid receptor antagonists CNQX and APV were included in the bathing media when the intracellular solution was $\mathrm{KCl}$ (140 $\mathrm{mm})$. In general, potassium gluconate was used fo- these experiments, and the membrane potential of the postsynaptic cell was clamped at either -70 or $-80 \mathrm{mV}$. It was found that the evoked currents were much smaller when recording with potassium gluconate electrodes (Fig. 1D). This reduced amplitude was due to a decreased driving force at negative holding potentials. For the five cells examined in detail, the amplitudes ranged from -128 to $-781 \mathrm{pA}$, with a mean $( \pm \mathrm{SD}$ ) of $-428 \pm 269$ (Table 1 ). When $\mathrm{KCl}$ was the major constituent of the electrode, the currents for six cells held at $-70 \mathrm{mV}$ ranged from -550 to $-5481 \mathrm{pA}$, with a mean ( \pm SEM) 
A.

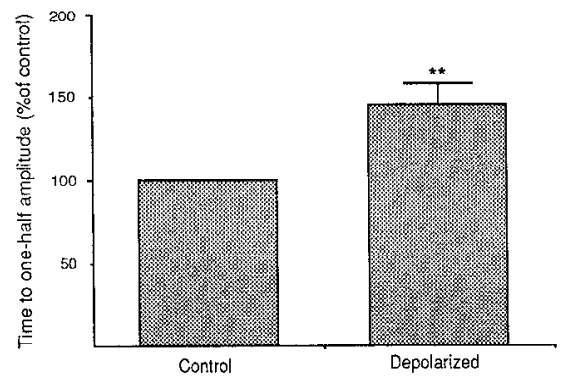

B.

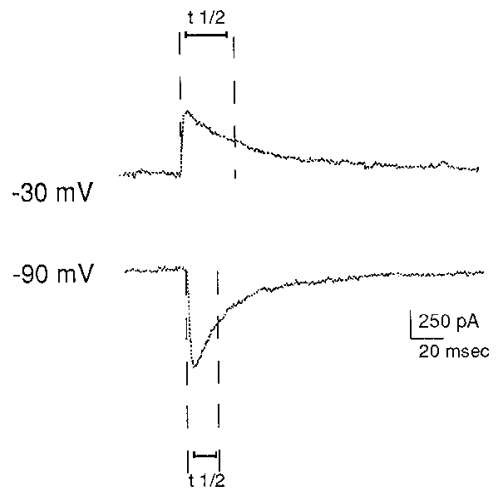

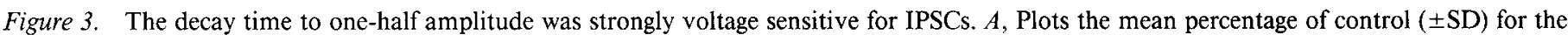

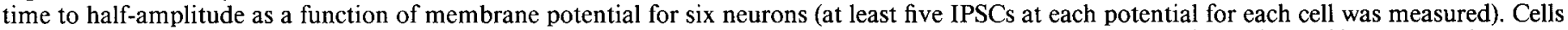

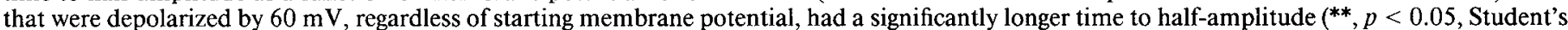

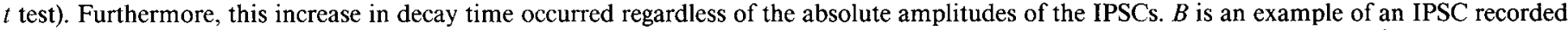

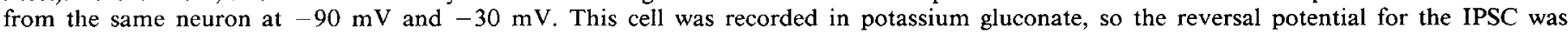

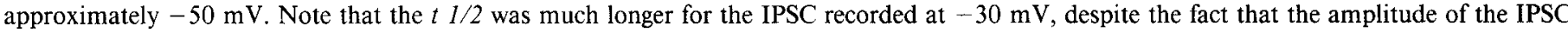
was larger at $-90 \mathrm{mV}$.

of $-2398 \pm 824 \mathrm{pA}$. The smaller currents recorded with potassium gluconate electrodes minimized errors in voltage due to the series resistance (Llano et al., 1991) and also reduced the chance that the evoked currents would initiate "active responses" in the neurons (Llano et al., 1991; Vincent et al., 1992). In addition, when $\mathrm{KCl}$ was used to record the presynaptic cell, an action potential was often followed by a prolonged afterdepolarization that was not present when potassium gluconate was used.

The specific $\mathrm{GABA}_{\mathrm{A}}$ receptor antagonist bicuculline methiodide $(10 \mu \mathrm{M})$ reversibly blocked the evoked currents (Fig. 2). The sensitivity of the reversal potential to changes in intracellular chloride concentration, and the block observed with bicuculline, indicated that these $\mathrm{Cl}^{-}$-dependent currents were mediated by the action potential dependent release of GABA and that the synapses were near the soma, as cable effects on the currents were not readily obvious. Therefore, these GABAergic inhibitory postsynaptic currents will be referred to as IPSCs. Consistent with published reports (Harrison et al., 1988; Harrison, 1990; Yoon and Rothman, 1991), there was never any evidence for the presence of a slow, outward component of the PSC that could be attributed to concomitant activation of postsynaptic $\mathrm{GABA}_{\mathrm{B}}$ receptors.

As has becn obscrved in similar preparations (Weiss ct al., 1988; Edwards et al., 1990; Ropert et al., 1990; Scanziani et al., 1992; Vautrin et al., 1992), at hyperpolarized potentials, small spontaneous inward currents persist in the presence of both TTX and antagonists of excitatory amino acid receptors. These miniature currents are completely blocked by bicuculline (Fig. $2 B$ ), suggesting that they are mediated by the action potential independent release of GABA, and accordingly will be referred to as mIPSCs (Wilcox and Dichter, 1991).

Unlike mIPSCs, the evoked responses observed under these conditions generally required the sum of two exponentials to fit to the decay phase of the currents. This is similar to what was observed by Edwards et al. (1990) for evoked responses in dentate cells of the hippocampal slice preparation, and given the mIPSC data obtained in this system under similar recording conditions (Wilcox and Dichter, 1991), this finding was some- what surprising. It was anticipated that the decay phase would correspond to that of the mIPSCs, and be fit quite readily with a single exponential (Ropert et al., 1990). For measurement purposes, the decay time to half-amplitude of the IPSC for five cells was determined, in an effort to ascertain the duration of the IPSC. As shown in Table 1, the decay time to half-amplitude had a mean of $16.6 \pm 2.3 \mathrm{msec}$ at a holding potential of -70 $\mathrm{mV}$ for five cells. Of particular interest with respect to the decay phase of the currents was the fact that as the membrane potential was depolarized, the decay of the current became prolonged. When the membrane potential was depolarized by $60 \mathrm{mV}$, the decay time to half-amplitude significantly increased $(p<0.001)$ for five cells examined in detail. The mean increase for a 60 $\mathrm{mV}$ depolarization, regardless of the initial $V_{m}$, was $45 \% \pm 13 \%$, and ranged from $31 \%$ to $65 \%$ (Fig. 3 ).

Low-frequency stimulation was required to ensure relatively stable amplitudes of the IPSCs. Stimulation frequencies of $>0.25$ $\mathrm{Hz}$ invariably resulted in decrementing amplitudes of the IPSCs. In general, the stimulation frequencies used in these experiments never exceeded $0.25 \mathrm{~Hz}$. Because such low frequencies of stimulation were necessary, it was difficult to acquire a large number of relatively stationary IPSCs. This was due to at least two factors: first, it was difficult to obtain two long-lasting patchclamp recordings that could maintain the integrity of both recordings, and second, some degree of current "rundown" was observed.

Figure 4 is a representative histogram of a distribution of amplitudes of evoked IPSCs recorded with a $\mathrm{KCl}$ electrode. A distribution of mIPSCs from the same recording are included for comparison. Although these miniature currents (minis) were not recorded in the presence of TTX, the presynaptic cell was being monitored and no spontaneous action potentials were observed during the course of the recording. The mode of the distribution (or peak of the Gaussian) for evoked IPSCs for this particular cell was $-770 \pm 71 \mathrm{pA}$, and the mean of the mIPSCs was $-25 \mathrm{pA}$. This suggests that for this pair of neurons, there were approximately 31 vesicles of neurotransmitter released that contributed to the amplitude of the IPSC at this concentration of calcium. This type of analysis was performed for a total of 


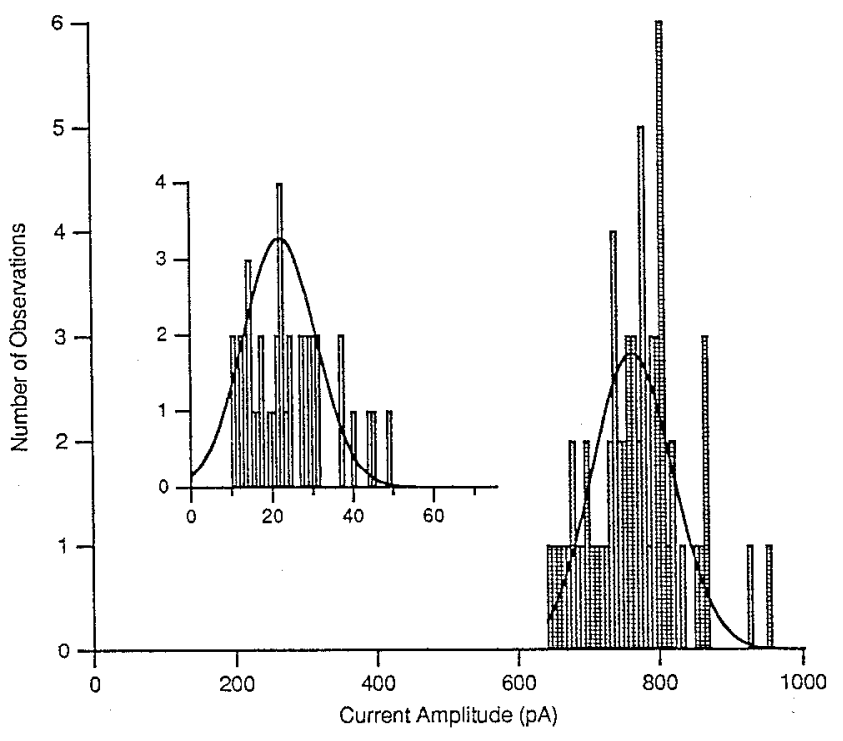

Figure 4. IPSCs evoked at a low frequency $(0.1 \mathrm{~Hz})$ have a relatively normal distribution. These IPSCs were measured using a $\mathrm{KCl}$ electrode, thereby making it possible to measure mIPSCs simultaneously in the same neuron (inset; see also Fig. 10). The mean amplitude of mIPSCs was $25 \mathrm{pA} \pm 10$, whereas the mean IPSC amplitude was $-770 \mathrm{pA} \pm$ 71 at a holding potential of $-70 \mathrm{mV}$.

six cells recorded under conditions of symmetrical chloride, and the mean $( \pm S D)$ number of quanta/IPSC was calculated to be $63.5 \pm 34$, with a range between 17 and 109 vesicles/IPSC per cell (if one vesicle $=$ one quanta).

\section{The effect of calcium concentration on IPSCS}

The evoked IPSCs were very sensitive to changes in the extracellular calcium concentration. In control conditions, in $4 \mathrm{~mm}$ $\mathrm{Ca}^{2+}$, there were never any failures as long as the presynaptic cell fired an action potential. However, as the calcium concentration was decreased from $4 \mathrm{~mm}$ to either $1 \mathrm{~mm}$ ( $n=6$ cells) or $0.5 \mathrm{~mm}$ ( $n=2$ cells), failures in transmission were observed. Furthermore, as the calcium concentration was decreased, the amplitude of the IPSC decreased (Fig. 5). The decreased calcium concentration had no measurable effect on any of the kinetics of the evoked currents. This can be observed by digitally scaling the reduced IPSC during conditions of low calcium and superimposing the trace over IPSCs acquired during control periods (Fig. 5). This suggests that a presynaptic sensitivity to calcium concentration that results in decreased neurotransmitter being released is responsible for the dramatic decrease in amplitude, and not that the kinetic properties of the postsynaptic channel are being altered by a lower calcium concentration. During these experiments, the divalent cation concentration was maintained at an equivalent concentration by increasing the amount of $\mathrm{Mg}^{2+}$ included in the solution as the calcium concentration was decreased.

\section{The effect of baclofen on IPSCS}

In some experiments, ( \pm )-baclofen $(2 \mu \mathrm{M}$ or $10 \mu \mathrm{M} ; n=4$ and 6 cells, respectively), a $\mathrm{GABA}_{\mathrm{B}}$ receptor agonist, was added to the perfusion media to determine if $\mathrm{GABA}_{\mathrm{B}}$ receptors were present on these neurons. Consistent with previous reports, perfusion of baclofen did not directly induce a current in the neuron being recorded, whereas it did significantly and reversibly reduce the amplitude of the evoked IPSCs (Fig. 6) (Harrison et al.,

\section{HBS $4 / 0$}

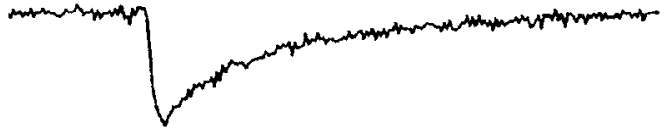

HBS $1 / 3$

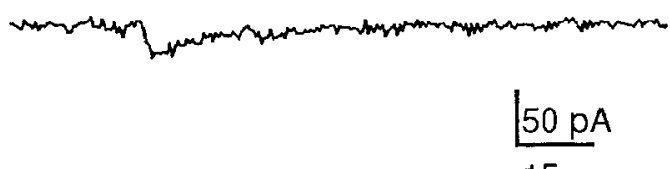

15 msec

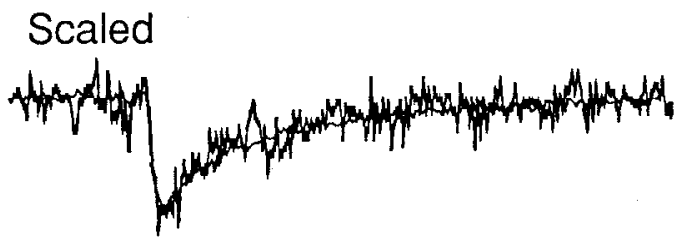

Figure 5. The amplitudes of the IPSCs are sensitive to the calcium concentration. As the divalent cation concentration of the extracellular solution is altered from $4.0 \mathrm{~mm}$ calcium $/ 0 \mathrm{~mm}$ magnesium ( $H B S 4 / 0$ ) to $1.0 \mathrm{~mm}$ calcium $/ 3.0 \mathrm{~mm}$ magnesium $(H B S 1 / 3)$, the amplitude of the IPSC is greatly reduced. However, if the smaller current is digitally scaled to the same size as the control IPSC and superimposed, it is possible to see that the kinetics of the response have not been altered.

1988; Harrison, 1990; Scholz and Miller, 1991). This action of haclofen has been demonstrated by several groups to be due to a presynaptic reduction in the amount of GABA released, and not due to a postsynaptic effect on $\mathrm{GABA}_{\mathrm{A}}$ or $\mathrm{GABA}_{\mathrm{B}}$ receptors (Forsythe and Clements, 1990; Harrison, 1990; Thompson and Gahwiler, 1992). The presence of these receptors suggests that there is a mechanism through which GABA release can feedback onto the presynaptic terminal to decrease subsequent release; thus these "auto-receptors" may play a role in the regulation of inhibition.

\section{The effect of paired pulse stimulation on IPSC'S}

At its most elementary form, frequency-dependent effects on synaptic inhibition can be seen with just two sequential IPSC's. IPSCs that are evoked with interstimulus intervals (ISIs) for up to $4 \mathrm{sec}$ routincly demonstrate a decrease in the amplitude of the second IPSC (Deisz and Prince, 1989; Davies et al., 1990; Yoon and Rothman, 1991; Otis and Mody, 1992; Mott et al., 1993 ) and this is known as PPD. In addition, in some preparations, tetanic stimulation results in a dramatic decrease in the amplitude of IPSCs for several seconds following a stimulus train (Ben-Ari et al., 1979; McCarren and Alger, 1985; Thompson and Gahwiler, 1989a-c).

Pairs of action potentials were elicited at various ISIs, and the effect on the IPSCs was determined. To ensure the relative stability of the amplitude of the first IPSC, the frequency with which these pairs of action potentials were evoked was never greater that $0.2 \mathrm{~Hz}$. A significant decrease in the amplitude of the second IPSC was recorded at ISIs ranging from $25 \mathrm{msec}$ to $4 \mathrm{sec}$ in greater than $95 \%$ of cells recorded ( $n=65$ pairs) (Fig. 7). (Not all cells were tested at all ISIs, but at least $95 \%$ of the 
Control
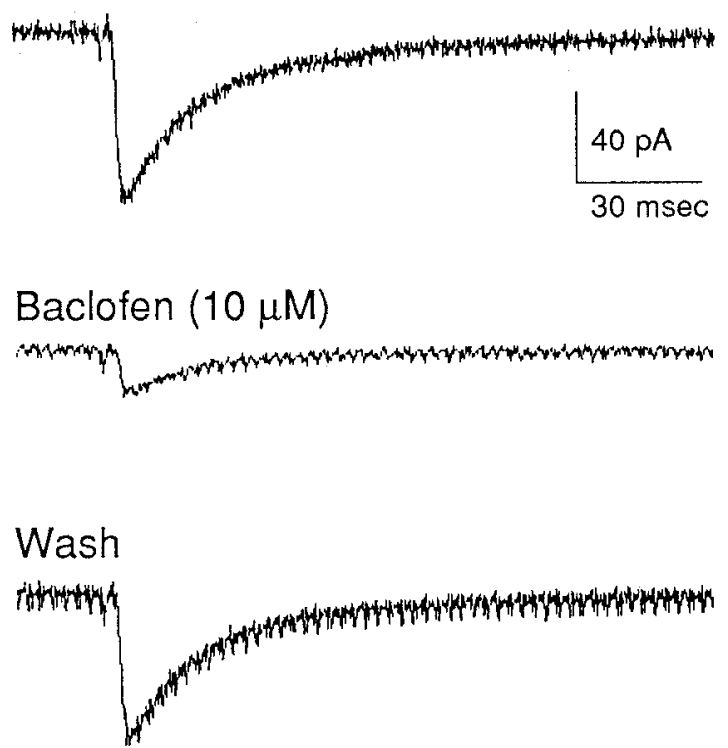

Figure 6. The amplitudes of the IPSCs are sensitive to presynaptic activation of $\mathrm{GABA}_{\mathrm{B}}$ receptors. IPSCs measured at a holding potential of $-70 \mathrm{mV}$ are inward, and decrease dramatically in the presence of ( \pm )-baclofen $(10 \mu \mathrm{M})$. This effect is reversible as seen in the bottom trace. In addition, $\mathrm{GABA}_{\mathrm{B}}$ receptor antagonists can block the effect of baclofen (see Fig. 10).

cells demonstrated robust PPD at ISIs within the range mentioned above.) This decrease in amplitude occurred when either $\mathrm{KCl}$ or potassium gluconate was the main constituent in the recording pipette of the postsynaptic cell. The PPD long outlasted the time course of single IPSCs, which was less than 250 msec. In general, the maximal depression observed in the second IPSC occurred with ISIs ranging from 50 to $400 \mathrm{msec}$. The amount of PPD was determined by dividing the amplitude of the depressed IPSC by the amplitude of the corresponding first IPSC. The mean of the ratios for at least seven trials was then calculated. No change in the amplitudes between the first and second IPSC would result in a ratio near 1.0 , whereas ratios below 1.0 would be observed if depression had occurred, while facilitation would result in ratios above 1.0. The mean ratio for five cells with ISIs of $100 \mathrm{msec}$ was $0.52 \pm 0.11$ (Table 2), with a range from 0.42 to 0.7 . It was found that the $\mathrm{CV}$ of the second IPSC was consistently much greater than that of the first IPSC (Table 2). This increase in variance suggests that a presynaptic mechanism underlies PPD (Forsythe and Clements, 1990; Har-
A.

B.

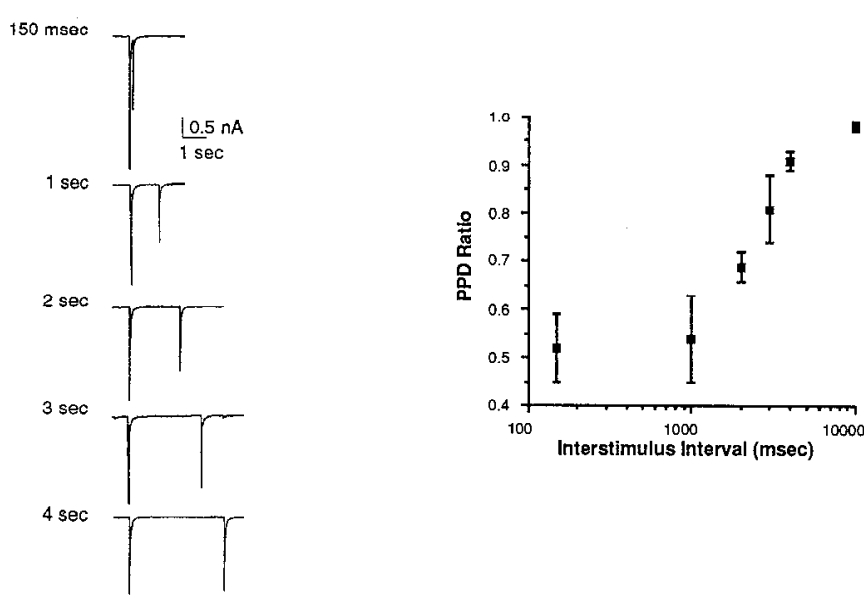

Figure 7. PPD of IPSCs occurs at presynaptic ISIs ranging from 150 msec to $4 \mathrm{sec}$. $A$ shows a series of pairs of IPSCs recorded at $-70 \mathrm{mV}$ at varying intervals. The longer the ISI, the less depression is observed. $B$ plots the ratio of the amplitude of the second IPSC/first IPSC as a function of ISI. As the interval increases from the millisecond to second range, the amplitude of the second IPSC approaches that of the first, provided that the intertrial interval is slow enough $(<0.25 \mathrm{~Hz})$. Data are from one cell and represents the mean depression $( \pm S D)$ for at least five IPSCs at each interval.

rison, 1990; Korn and Faber, 1987). If a postsynaptic mechanism is responsible for changes in the mean PSC amplitude, then a concomitant change in the SD would be observed and no overall change in the $\mathrm{CV}$ would have occurred (Korn and Faber, 1991).

There was no significant change in either the mean rise time to the peak amplitude or the mean decay time to half-amplitude from the first to second pulsc (Table 3, Fig. 8). In three of the cells, a pairwise comparison of the IPSCs for each particular trial revealed a significant decrease in the decay time. However, a pairwise comparison between the means for all cells did not result in an overall significant difference.

\section{Localization of the mechanism underlying PPD}

The next series of experiments were designed to determine the location of the mechanism underlying PPD. To determine if there was a change in the postsynaptic driving force for chloride following the paired stimuli, a current-voltage curve was constructed for both IPSCs. Amplitudes were measured from the

Table 2. Analysis of PPD of IPSCs (100 msec ISI)

\begin{tabular}{lllllr} 
Cell & $\begin{array}{l}\text { Amplitude of } \\
\text { IPSC 1 }(\mathrm{pA})\end{array}$ & CV 1 & $\begin{array}{l}\text { Amplitude of } \\
\text { IPSC 2 (pA) }\end{array}$ & CV 2 & \multicolumn{1}{c}{ PPD ratio } \\
\hline $1(n=7)$ & $-243+17$ & 0.07 & $-135+24$ & 0.18 & $0.55 \pm 0.08$ \\
$2(n=16)$ & $-781 \pm 59$ & 0.08 & $-513 \pm 43$ & 0.08 & $0.7 \pm 0.07$ \\
$3(n=15)$ & $-167 \pm 15$ & 0.09 & $-70 \pm 12$ & 0.17 & $0.42 \pm 0.10$ \\
$4(n=42)$ & $-361 \pm 26$ & 0.08 & $-171 \pm 42$ & 0.25 & $0.49 \pm 0.10$ \\
$5(n=16)$ & $-106 \pm 7$ & 0.07 & $-46 \pm 8.7$ & 0.15 & $0.44 \pm 0.08$ \\
Mean \pm SD & $-331 \pm 268$ & $0.08 \pm 0.01$ & $-187 \pm 189^{*}$ & $0.17 \pm 0.06^{*}$ & $0.52 \pm 0.11$
\end{tabular}

The number of IPSCs evaluated for each cell for all parameters (mean \pm SD) is listed in parentheses next to each cell. A pairwise comparison for the Student's $t$ test was used to check for differences between the mean values between groups for amplitudes and CVs. $(*, p<0.05)$. 


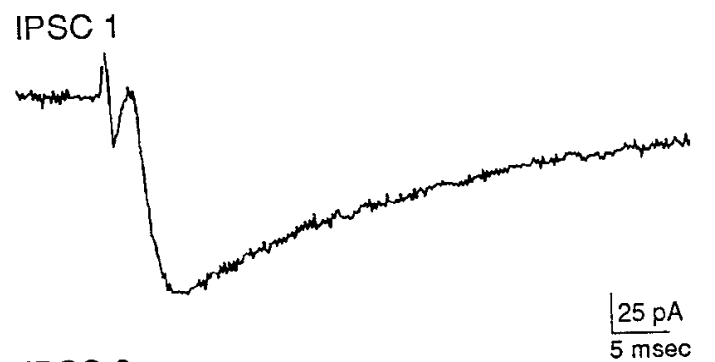

IPSC 2
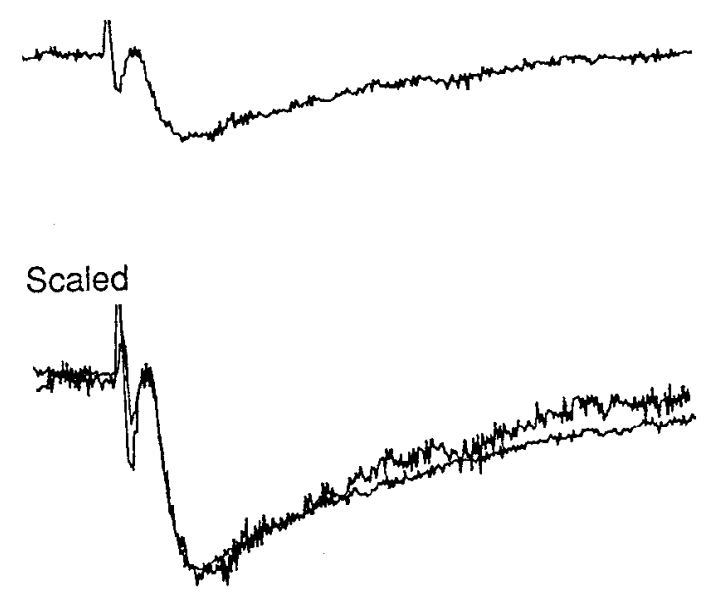

Figure 8. Although the current of a second IPSC is attenuated, PPD has very little effect on the kinetics of the IPSC. IPSCs elicited with a $100 \mathrm{msec}$ ISI exhibit a large degree of depression. However, when digitally scaled to the size of the first, superimposition reveals very little effect on either the latency or rise time of the response. However, some cells did show a small decrease in the time course of decay of the second IPSC.

peak of both IPSCs and plotted as a function of voltage ( $n=$ 6). As demonstrated in Figure 9, the reversal potential was not altered from the first to the second current, regardless of the internal solution used for the postsynaptic recording. This indicates that, unlike repetitive stimulation, a change in postsynaptic chloride driving force can not be responsible for PPD at depolarized potentials (Ben-Ari et al., 1979; McCarren and Alger, 1985; Thompson and Gahwiler, 1989a,b). In order for a

Table 3. Comparison of rise times and the decays to one-half amplitude for the first and second IPSC in a paired-pulse experiment (100 msec ISI)

\begin{tabular}{|c|c|c|c|c|}
\hline \multirow[b]{2}{*}{ Cell } & \multicolumn{2}{|c|}{ Rise time (msec) } & \multicolumn{2}{|c|}{$\begin{array}{l}\text { Decay to } 1 / 2 \text { amplitude } \\
\text { (msec) }\end{array}$} \\
\hline & IPSC 1 & IPSC 2 & IPSC 1 & IPSC 2 \\
\hline $1(n=7)$ & $3.4 \pm 0.4$ & $3.3 \pm 0.5$ & $24.7 \pm 1.5$ & $19.0 \pm 2.7^{*}$ \\
\hline $2(n=16)$ & $3.1 \pm 0.4$ & $3.0 \pm 0.5$ & $17.5 \pm 0.8$ & $16.1 \pm 1.1^{*}$ \\
\hline $3(n=15)$ & $2.4 \pm 0.3$ & $2.6 \pm 0.9$ & $17 \pm 1.6$ & $18.0 \pm 3.3$ \\
\hline $4(n=16)$ & $2.1 \pm 0.3$ & $2.2 \pm 0.3$ & $12.7 \pm 0.8$ & $11.9 \pm 0.8^{*}$ \\
\hline $5(n=16)$ & $2.3 \pm 0.4$ & $2.5 \pm 0.5$ & $14.0 \pm 1.9$ & $13.2 \pm 2.3$ \\
\hline Mean \pm SD & $2.7 \pm 0.6$ & $2.7 \pm 0.4$ & $17.2 \pm 4.7$ & $15.6 \pm 3.0$ \\
\hline
\end{tabular}

As in the preceding tables, the number of IPSCs evaluated for each cell is listed in parentheses next to the cell number. Rise time and decay time data were analyzed for the same set of IPSCs as in Table 2. Values represent the mean $\pm S D$. Individual differences in decay time that were significant are marked $\left({ }^{*}\right)$. A pairwise comparison of the overall means for the decay time to one-half amplitude was not significantly different.
A.

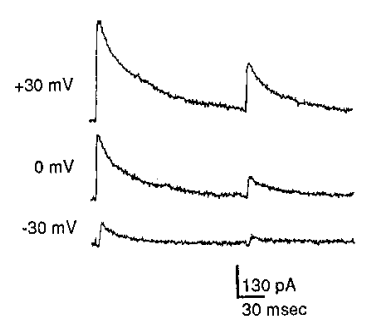

B.

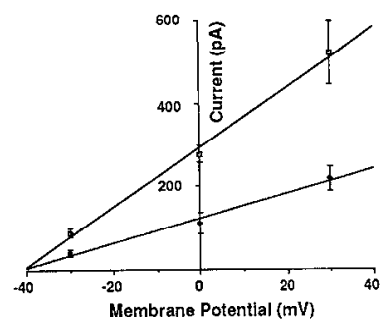

C.

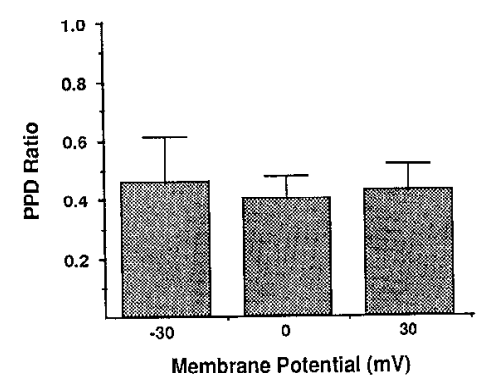

Figure 9. IPSCs recorded using the whole-cell patch-clamp technique from pairs of hippocampal neurons in low-density culture exhibit robust PPD lasting for several seconds at all membrane potentials. $A$, PPD of current traces at various membrane potentials. Note that as the membrane potential is depolarized, the time to half-amplitude of both IPSCs increases. $B$, Current-voltage plot of the first ( $\square$ ) and the second IPSC $(\checkmark)$ in a cell recorded with a potassium gluconate electrode. The reversal potential does not change between pulses, indicating that a change in driving force is not responsible for the decreased current of the second IPSC. Each point represents the mean \pm SD of at least seven IPSCs at each potential. $C$, The mean PPD ratio $( \pm$ SD) of pairs of IPSCs is plotted as a function of membrane potential. The depression was calculated by dividing the peak current of the second IPSC by that of the first for at least seven trials at each potential. The Student's $t$ test was used to compare groups. No significant differences were observed. $A-$ $C$ are from the same recording.

reversal potential change to have been responsible for the dramatic decrease observed for the cell in Figure 9, a $30 \mathrm{mV}$ hyperpolarization of the reversal potential would have been required, and this was clearly not observed. In addition, it was found that, although the IPSCs were greatly prolonged at depolarized membrane potentials, the amount of PPD was unaffected by postsynaptic membrane potential (Fig. 9) ( $n=6$ pairs)

To determine directly if PPD was due to a pre-or postsynaptic mechanism, the amplitudes of spontaneous mIPSCs were measured (Wilcox and Dichter, 1991) during the interval between successively evoked IPSCs $(0.1-0.12 \mathrm{~Hz}$ ) (Fig. 10A). Unlike brain slice preparations, this culture system made it possible to assay a majority of the same postsynaptic receptors that are activated during evoked release of GABA (Korn and Faber, 1991; Manabe et al., 1992; Otis and Mody, 1992). The analysis of miniature currents has been viewed as a direct measure for assessing the location of synaptic plasticity changes (del Castillo and Katz, 1954; Redman, 1990; Korn and Faber, 1991; Malgaroli and Tsien, 1992; Manabe et al., 1992; Otis and Mody, 1992), whereas the method of failures and the ANOVA technique are indirect methods to determine the location of synaptic 
A.

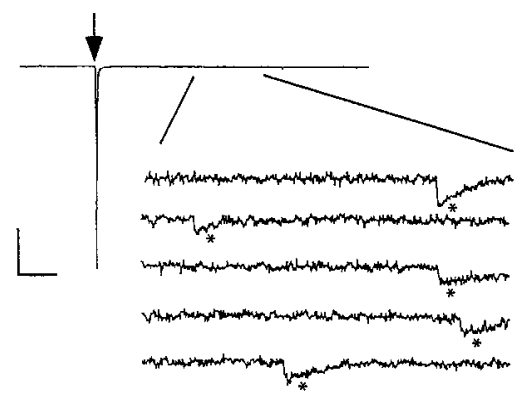

C.

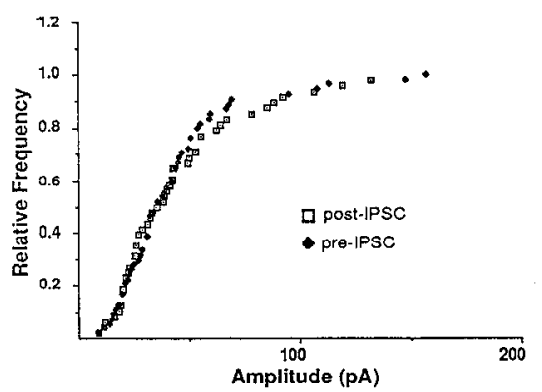

B.

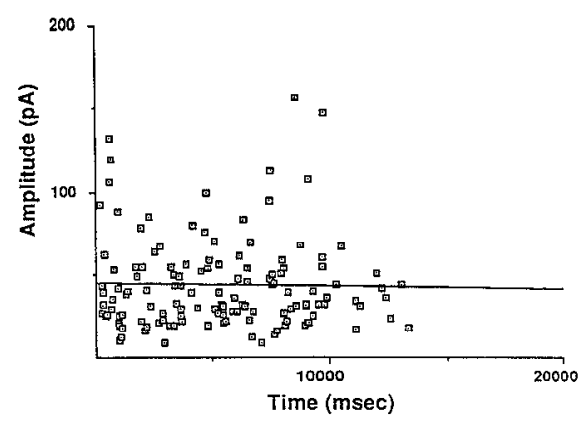

D.

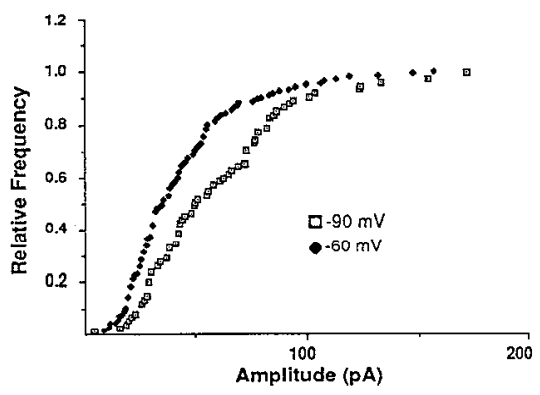

Figure 10. Evoked IPSCs and subsequent miniature currents. A, Example of evoked (arrow) IPSC. At a higher gain and faster sweep speed, spontaneous miniature currents can be resolved $\left({ }^{*}\right)$ (see also Fig. 2). The postsynaptic electrode contained $\mathrm{KCl}(140 \mathrm{~mm})$ instead of K-gluconate,

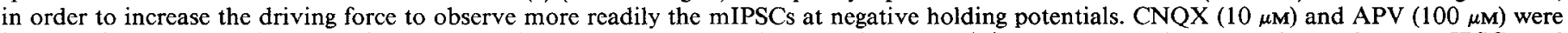
included in the extracellular solution to block glutamate receptors and ensure that any miniature currents that were observed were mIPSCs and did not arise from excitatory autapses. Calibration: $1 \mathrm{nA} / 1.3 \mathrm{sec}$ for IPSC and $100 \mathrm{pA} / 20 \mathrm{msec}$ for the miniature currents $\left(V_{m}=-60 \mathrm{mV}\right)$. $B$, Plot of peak amplitudes of mIPSCs as a function of time following the onset of the IPSC. Data were collected for greater than 35 sweeps to have a large number of mIPSCs $\left(V_{m}=-60 \mathrm{mV}\right)$. The slope of the line fit to the curve was not significantly different from zero. Cumulative histograms plot the relative frequency with which various amplitudes of all minis occur. $C$ plots the frequency of mIPSCs that occur up to 3.5 sec following an evoked IPSC $(\square)$ and $3.5 \mathrm{sec}$ prior to the next IPSC ( ). Note that there is a complete overlap of the amplitudes in both epochs and that the distributions are not significantly different. $D$, A cumulative histogram demonstrates that as the membrane potential increases from $-60 \mathrm{mV}(\$)$ to $-90 \mathrm{mV}(\square)$, the frequency of larger amplitude currents significantly increases (Kolmogorov-Smirnov statistic, $p<0.04$ ), as demonstrated by the curve shifting to the right.

plasticity that are used when miniature currents are not readily resolved. If PPD was due to a postsynaptic mechanism, the amplitude of the mIPSCs immediately following an IPSC would initially be decreased, and would gradually increase to control values during the latter seconds of the ISI. Although these mIPSCs were not recorded in the presence of TTX, the presynaptic neurons were being monitored, and no spontaneous action potentials were observed during the period in which mIPSCs were collected. In addition, the mean amplitudes of the population of mIPSCs were not any larger than those recorded under similar conditions (Wilcox and Dichter, 1991). No change in the amplitudes of the miniature currents was observed during any part of the post-IPSC period ( $n=6$ cells) (Fig. $10 B, C$ ), despite the fact that PPD lasted for up to $4 \mathrm{sec}$. In addition, there was no change in the frequency with which these currents occurred following an evoked IPSC. Cumulative histograms of the mIPSC amplitudes at various epochs following the IPSC were unaltered (Fig. 10C) (Van Der Kloot, 1991; Malgaroli and Tsien, 1992; Manabe et al., 1992; Otis and Mody, 1992). This measure can be significantly affected by manipulations that alter postsynaptic GABA responses, such as changing the postsynaptic membrane potential to modify the chloride driving force (Fig. 10D). In
Figure $10 D$, the membrane potential was varied by $30 \mathrm{mV}$ in order to test whether or not it was possible to discern any changes in the amplitudes of the mIPSCs. A difference of $30 \mathrm{mV}$ was chosen because, as stated above, in order for a reversal potential change to have been responsible for the observed decreases, a $30 \mathrm{mV}$ shift in the $I-V$ curve would have been needed. Therefore, Figure $10 D$ demonstrates that it would be possible to resolve either an increase or a decrease in mIPSC amplitude. None of the cells tested in this way demonstrated a significant change in the observed mIPSC amplitude following the evoked IPSCs; therefore, it was concluded that PPD between these neurons was due to a presynaptic mechanism.

\section{Role of presynaptic $G A B A_{B}$ receptors in PPD}

To determine if autoinhibition via activation of presynaptic $\mathrm{GABA}_{\mathrm{B}}$ receptors was responsible for the decrease in the amplitude of the second evoked current, the $\mathrm{GABA}_{\mathrm{B}}$ receptor antagonist CGP-35348 $(100 \mu \mathrm{M})$ was perfused into the bathing solution ( $n=5$ cells) while trains of paired IPSCs were recorded (Bittiger et al., 1990; Olpe et al., 1990; Davies et al., 1991; Mott et al., 1993) (Fig. 11). No effect on either the amplitude of the IPSCs or the degree of PPD was observed. This concentration 
A.
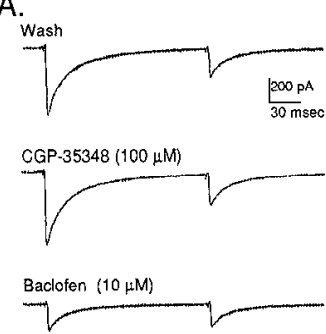

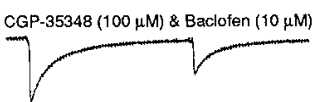

C.

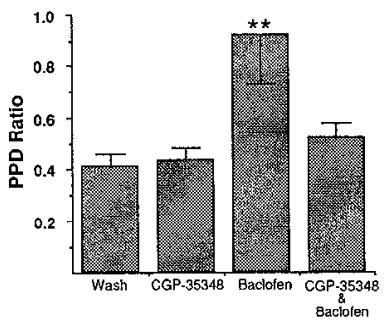

Figure 11. PPD is unaffected by the selective GABA $_{\mathrm{B}}$ receptor antagonist CGP-35348. $A$ shows traces of pairs of evoked IPSCs under various conditions. Each trace is the average of at least seven trials for each condition. Presynaptic action potentials occurred at an ISI of $150 \mathrm{msec}$, at a frequency of $0.16 \mathrm{~Hz}$. CGP-35348 $(100 \mu \mathrm{M})$ has no effect on the IPSCs or the degree of PPD exhibited. When ( \pm )-baclofen $(10 \mu \mathrm{M})$ is perfused into the bath, the amplitude of the first IPSC is greatly reduced and PPD is eliminated. However, CGP-35348 (100 $\mu \mathrm{M})$ completely reverses the block when coperfused with baclofen. $B$ plots the mean amplitude $( \pm$ SD) of IPSC 1 and IPSC 2 for each condition for the same cell that is in $A$. Each bar represents a series of currents greater than eight trials each. $C$ plots the mean PPD ratio $( \pm \mathrm{SD})$ for each condition for the same cell. Note that therc is no significant effect of CGP-35348 alone on PPD, yet it does reverse the effects of baclofen. $\left({ }^{* *}, p<0.05\right.$, Student's $t$ test).

of CGP-35348 completely reversed the actions of $10 \mu \mathrm{M}( \pm)$ baclofen ( $n=3$ cells), indicating that this compound does indeed act at the presynaptic $\mathrm{GABA}_{\mathrm{B}}$ receptor in these cells (Fig. 11).

Two other antagonists of the $\mathrm{GABA}_{\mathrm{B}}$ receptor were tested to determine if PPD could be modulated: 2-OH-saclofen and phaclofen (Deisz and Prince, 1989; Davies et al., 1990; Harrison et al., 1990; Yoon and Rothman, 1991; Mott et al., 1993). Although saclofen significantly decreased the amplitudes of both evoked currents during a trial $(p<0.001$, Student's $t$ test), there was no effect on the degree of PPD (Fig. 12). Phaclofen, a less specific $\mathrm{GABA}_{\mathrm{B}}$ receptor antagonist (Davies et al., 1990; Yoon and Rothman, 1991), was perfused into the bath ( $n=5$ cells) and was also ineffective in blocking the PPD (Fig. 12). Thus, there is no evidence to suggest that PPD was due to activation of presynaptic $\mathrm{GABA}_{\mathrm{B}}$ receptors, since three antagonists (at concentrations sufficient to block the action of baclofen) for the receptor neither attenuated nor blocked PPD.

\section{Altering the probability of release effects $P P D$}

It has been demonstrated at excitatory synapses that the probability of release of neurotransmitter under baseline conditions significantly influences synaptic responses to repetitive activation (e.g., synapses with high probabilities of release tend to decrement and those with low probabilitics of release tend to facilitate with repetitive activation (Korn and Faber, 1987; Zucker, 1988). Accordingly, we would predict that by reducing the overall probability of release of GABA in our system, we could reduce or eliminate PPD (Thies, 1965). Therefore, the effect on PPD of changing the concentration of calcium was tested. When the extracellular divalent cation concentration was altered from $4.0 \mathrm{mM} \mathrm{Ca} \mathrm{a}^{2}$ and $0 \mathrm{~mm} \mathrm{Mg}^{2+}$ to $1.0 \mathrm{mM} \mathrm{Ca}^{2+}$ and $3.0 \mathrm{mM} \mathrm{Mg}^{2+}(n=5$ cells), PPD was significantly reduced $(p<$ 0.001 ) (Fig. 13), as was the amplitude of both IPSCs. In addition, the SD of the PPD in the presence of low calcium became larger, as expected following a presynaptic manipulation of the release process. As the amplitude of the first IPSC decreased, facilitation of the synapse often occurred. If there was a failure for either of the IPSCs, then that particular trial was not counted. Figure $13 C$ demonstrates the relationship between the amplitude of the first IPSC and the degree to which the second IPSC is either depressed or facilitated under conditions of low calcium. As Figure 13 demonstrates, facilitation occurred most readily when the first IPSC was quite reduced. This suggests that a variety of synaptic mechanisms interact to determine the amplitude of IPSCs following various patterns of presynaptic activity.

Similarly, when the presynaptic $\mathrm{GABA}_{\mathrm{B}}$ agonist ( \pm )-baclofen ( $2 \mu \mathrm{M}$ or $10 \mu \mathrm{M}$ ) was perfused into the bathing media ( $n=4$ and 6 cells, respectively), the amplitudes of both currents were again greatly reduced and PPD was again significantly diminished, as has been reported for the brain slice (Davies et al., 1990) (Fig. 14; see also Fig. 6). As was observed for the calcium experiments described above, there was a strong relationship between the amplitude of the first IPSC and the degree to which the neuron demonstrated depression or facilitation (Fig. 14).

\section{Discussion}

Whole-cell, patch-clamp recordings of isolated pairs of neurons in the low-density tissue culture preparation have demonstrated that it is possible to record IPSCs that are monosynaptically evoked. This technique is a powerful way to examine the fine properties of central synaptic transmission, as it is possible to monitor directly both the pre- and postsynaptic neurons simultaneously. In addition, the whole-cell, patch-clamp technique also provides the resolution required to monitor miniature PSCs that occur spontaneously and independently of presynaptic action potentials and that provide a direct measure of $q$, the quantal amplitude.

A limitation was also noted for this experimental paradigm. The rundown of the evoked currents, coupled with the necessity of low frequencies of stimulation $(<0.25 \mathrm{~Hz})$, made it difficult to acquire large numbers of PSCs for plotting amplitude distributions that met requirements for stationarity and to which a full quantal analysis could be applied. The rundown observed was surprising in light of the fact that miniature currents do not exhibit much time-dependent rundown (Wilcox and Dichter, 1991). This discrepancy is most readily explained by the fact that in the experiments performed here, the presynaptic cell is being dialyzed with intracellular solution, whereas in the miniature experiments, only the postsynaptic cell is being dialyzed. Perhaps then, a critical presynaptic intracellular component for the neurotransmitter vesicle release mechanism is decreased over time, resulting in the rundown observed. Indeed, work by Forsythe and Clements (1990) have demonstrated that loose patch recordings of presynaptic cells, in which the presynaptic 
A.

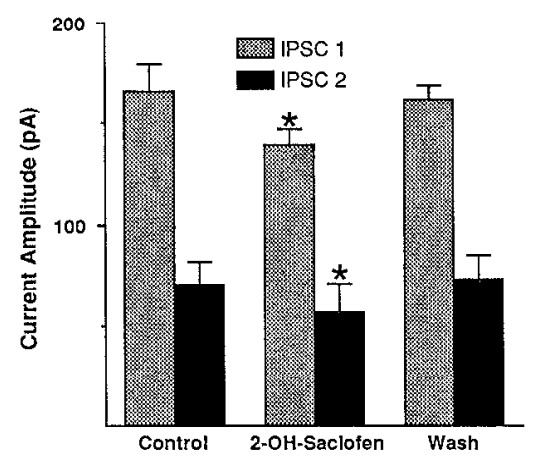

C.

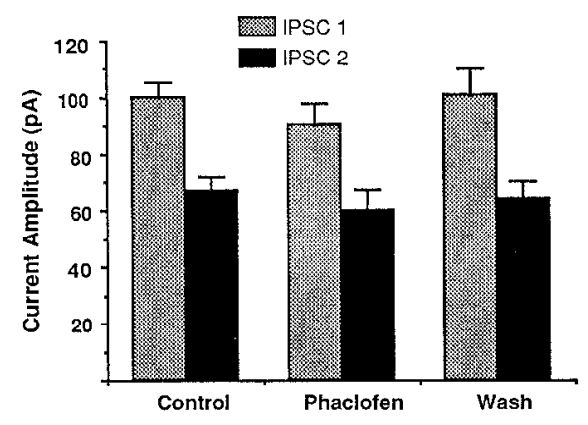

B.

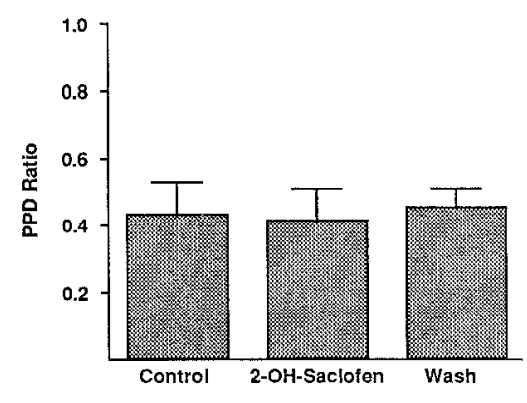

D.

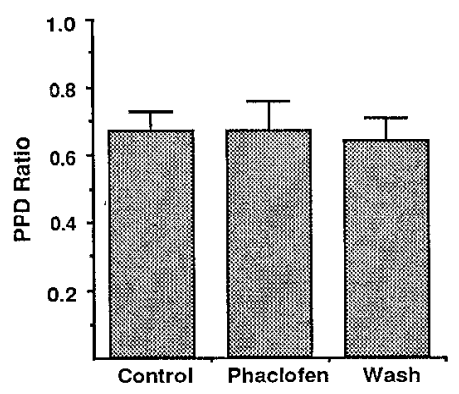

Figure 12. PPD is unaffected by $2-\mathrm{OH}-$ saclofen $\left(100 \mu_{\mathrm{M}}\right)$, a $\mathrm{GABA}_{\mathrm{B}}$ receptor antagonist. $A$, Plots of amplitudes of the first and second IPSCs in a series of trials with ISIs of $100 \mathrm{msec}$ (holding potential $=-70 \mathrm{mV}$ ) delivered at a frequency of $0.25 \mathrm{~Hz}$, for control bath, 2-OH-saclofen $(100 \mu \mathrm{M})$, and return to control. Each bar is the mean amplitude \pm SD for a set of currents greater than five trials each. The amplitudes of both the first and second IPSCs are significantly reduced during saclofen administration $\left(^{*}, p<0.05\right.$, Student's $t$ test). $B$, A plot of the percentage of PPD (mean \pm SD) for the same sets of trials as in $A$. PPD for the three conditions were not significantly different when compared with a Student's $t$ test. PPD is also unaffected by phaclofen $(100 \mu \mathrm{M})$, a $\mathrm{GABA}_{\mathrm{B}}$ receptor antagonist. $C$ plots the mean amplitudes $( \pm S D)$ of the first and second IPSCs under control, phaclofen $(100 \mu \mathrm{M})$, and wash condition. Each condition represents data from at least 12 pairs of stimuli. The ISI was $100 \mathrm{msec}$, and pairs of stimuli were delivered at $0.12 \mathrm{~Hz}$. Amplitudes were not significantly altered as a result of application of the $\mathrm{GABA}_{\mathrm{B}}$ antagonist. $D$, PPD ratio (mean $\pm \mathrm{SD}$ ) for the same three bath conditions as in $A$. The conditions were not significantly different when compared with a Student's $t$ test. cell is not dialyzed, greatly diminish the rundown observed in evoked EPSCs.

Although the amplitudes of the IPSCs did decrease over time, this did not, in general, interfere with experiments. It was pos- sible to look at short epochs of evoked PSCs, switch conditions for a couple of minutes, and return to control, with sufficient data to demonstrate significant and reversible changes of the evoked PSCs. Therefore, it was concluded that this system was
A.

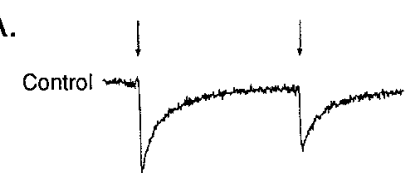

Low calcium

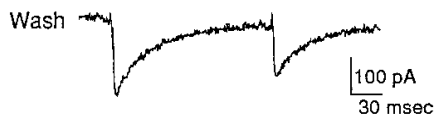

C.

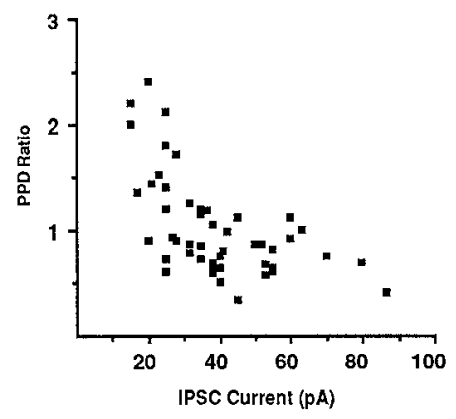

B.

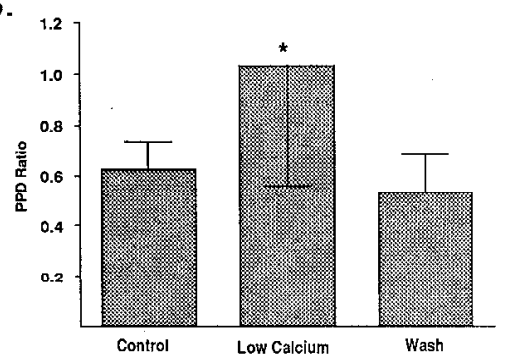

Figure 13. Effect of lowering the probability of release of the first IPSC on PPD. $A$, Current traces of pairs of IPSCs recorded in control, low calcium, and return to control conditions. Note that in this example, the second IPSC in the low-calcium condition actually demonstrates facilitation. $B$, Plots of the ratio of PPD (mean \pm SD) observed when low concentrations of calcium (1 $\mathrm{mm}$ $\mathrm{Ca}^{2+} / 3.0 \mathrm{~mm} \mathrm{Mg}^{2+}$ ) were substituted for the control concentrations of divalent cations ( $4.0 \mathrm{mM} \mathrm{Ca}^{2+} / 0 \mathrm{~mm} \mathrm{Mg}^{2+}$ ). Each point is the mean \pm SD for over 24 trials in each condition for a single pair. PPD was significantly reduced (*, $p<0.001$, Student's $t$ test) in this, as well as in four other cells. $C$ plots the PPD ratio as a function of the amplitude of the first IPSC under the lowcalcium condition. Note the very steep relation between the ratio of PPD and amplitude of the first IPSC. 
A.

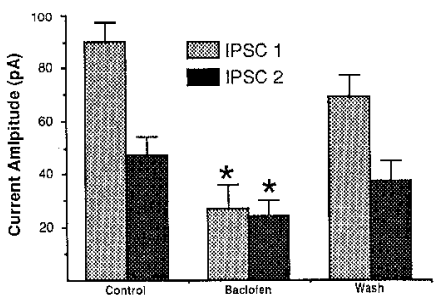

B.

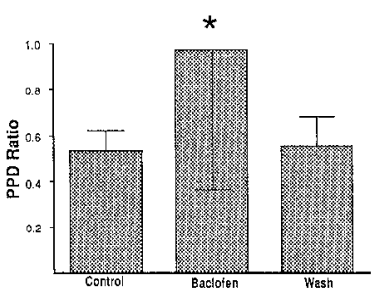

C.

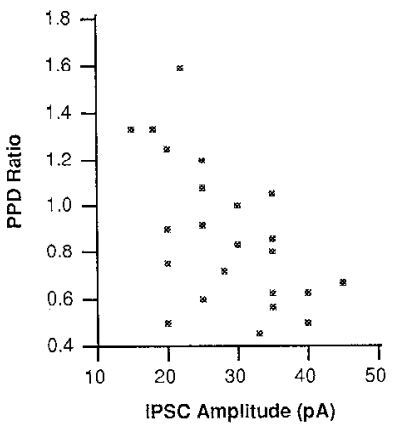

Figure 14. Effect of ( \pm -baclofen $(2 \mu \mathrm{M})$, a $\mathrm{GABA}_{\mathrm{B}}$ agonist, on the degree of PPD expressed. When baclofen was perfused into the bath ( $n$ $=33$ trials for this cell), the amplitudes (means \pm SD) of both the first and second IPSCs were significantly and reversibly decreased $\left(A ;{ }^{*}, p\right.$ $<0.05$ ) and the amount of PPD (means \pm SD) was again significantly decreased $\left(B ;{ }^{*}, p<0.05\right)$. $C$, As was the case in the presence of low calcium, the degree to which PPD was blocked was steeply dependent on the amplitude of the first IPSC.

a viable experimental model in which to examine the fine details of monosynaptic neurotransmission.

\section{Evoked IPSCS}

The fast IPSCs observed in these experiments were due to the action potential-dependent release of GABA, which crosses the synaptic cleft to bind and activate $\mathrm{GABA}_{\mathrm{A}}$ receptors. This $\mathrm{Ca}^{2+}$ dependent process results in the increased permeability of $\mathrm{Cl}^{-}$ and, under the recording conditions used here, causes an inward current at negative holding potentials. When $\mathrm{KCl}$ was used as the major constituent of the intracellular solution, it was possible to resolve mIPSCs in the same cell as the evoked IPSC. The mean amplitudes of the miniature currents recorded under these conditions were similar to those observed under TTX, and ranged from $25 \mathrm{pA}$ to $-50 \mathrm{pA}$, with a mean for six cells of $-36 \mathrm{pA}$ (Wilcox and Dichter, 1991).

In the hippocampal slice preparation (and the cultured hippocampal slice preparation), strong external stimulation of GABAergic afferents to various cell types results in a two-component IPSC; a fast chloride-mediated component, followed by a slower outward current that is due to a $\mathrm{GABA}_{\mathrm{B}}$ receptor-mediated increased $\mathrm{K}$ conductance (Dutar and Nicoll, 1988; Davies et al., 1990; Otis and Mody, 1992; Thompson and Gahwiler, 1992). However, this late IPSC is only observed when large stimulations are used, and in fact TTX-sensitive spontaneous IPSCs in the hippocampal slice do not activate the GA$\mathrm{BA}_{\mathrm{B}}$ receptor component (Otis and Mody, 1992). It has not been possible to determine if the postsynaptic $\mathrm{GABA}_{\mathrm{B}}$ receptors are activated following single evoked action potentials in that preparation, as it is extremely difficult to record from monosynap- tically connected pairs in the slice preparation. Furthermore, as the $\mathrm{GABA}_{\mathrm{B}}$ receptor component is associated with activation of a pertussis toxin-sensitive G-protein, it is necessary to include GTP in recording pipettes to prevent rapid rundown of this component. Although GTP was not included in the intracellular solution of these experiments, there was never any evidence for a postsynaptic GABA $_{B}$ component in the early minutes of the recording, nor was there any direct postsynaptic effect of perfusion with baclofen, as would be expected if there was a postsynaptic $\mathrm{GABA}_{\mathrm{B}}$ receptor. Therefore, it was concluded that in these cultures, functional $\mathrm{GABA}_{\mathrm{B}}$ receptors are not located postsynaptically (Harrison, 1990; Yoon and Rothman, 1991), and that the bicuculline-sensitive IPSCs recorded here are due to the selective activation of $\mathrm{GABA}_{\mathrm{A}}$ receptors.

Although there was no evidence for postsynaptic $\mathrm{GABA}_{\mathrm{B}}$ receptors in this preparation, the amount of neurotransmitter that was released was quite sensitive to the application of baclofen, a $\mathrm{GABA}_{\mathrm{B}}$ receptor agonist. This effect of baclofen was completely blocked by the selective $\mathrm{GABA}_{\mathrm{B}}$ receptor antagonist CGP35348. This suggests that there is a $\mathrm{GABA}_{\mathrm{B}}$ receptor located at the presynaptic terminal, and that there is the potential for released GABA to feed back on inhibitory terminals to regulate subsequent release. Such presynaptic $\mathrm{GABA}_{\mathrm{B}}$ receptors have been reported for many hippocampal preparations, although the mechanism through which activation of the receptor inhibits release is unknown at this time. It has been suggested that this presynaptic receptor is linked to a pertussis toxin-sensitive $\mathrm{G}$-protein, the activation of which increases the membrane permeability to $\mathrm{K}^{+}$(Yoon and Rothman, 1991; Thompson and Gahwiler, 1992), although some studies have been unable to block the presynaptic action of baclofen following pertussis toxin treatment (Dutar and Nicoll, 1988; Harrison, 1990). In those studies, it was hypothesized that baclofen was directly reducing calcium influx into the depolarized terminals, as it has been shown to do in cultured sensory neurons and hippocampal neurons as well (Dolphin and Scott, 1987; Dutar and Nicoll, 1988; Harrison, 1990; Scholz and Miller, 1991). The mechanism of the actions of baclofen were not investigated in this series of experiments, although future studies should be directed toward understanding the actions of this compound and the subsequent effect of reduced neurotransmission.

\section{Localization of the mechanism underlying PPD}

The most remarkable finding of this series of experiments was the very robust occurrence of PPD of IPSCs. A decreased amplitude of IPSCs was observed for up to $4 \mathrm{sec}$ following a single IPSC. This PPD was similar in degree and duration to what has been observed in the hippocampal brain slice (Deisz and Prince, 1989; Davies et al., 1990; Otis and Mody, 1992; Mott et al., 1993), as well as cultured slices (Thompson and Gahwiler, 1992) and cultured hippocampal neurons (Yoon and Rothman, 1991). Other than a decrease in amplitude, changes in other parameters of the second IPSC, such as latency and rise time, were not observed. The mechanism underlying this robust PPD has been hypothesized to be either postsynaptic or presynaptic in origin. This low-density tissue culture preparation is an ideal system to design rather direct experiments in which to examine the mechanisms underlying PPD.

Both presynaptic and postsynaptic mechanisms have been hypothesized to explain the reduction of GABAergic inhibition observed with long trains of repetitive stimulation and these hypotheses have been extrapolated to explain the more simple 
form of disinhibition observed with PPD. In these experiments, we attempted to systematically and directly test these hypotheses using a very simple CNS model. The simultaneous recording of isolated pairs of cells in this very low-density culture system of hippocampal neurons provides an elegant experimental paradigm in which to investigate such complex issues of synaptic plasticity.

Analysis of the current-voltage relationships of the IPSCs revealed that there was no change in the reversal potential from the first to second IPSC. A change in the chloride driving force, the ion mediating the IPSC observed in the postsynaptic neuron, could conceivably explain the decrease in the current amplitudes at depolarized potentials (Thompson and Gahwiler, 1989a-c). However, a $30 \mathrm{mV}$ shift in the current-voltage relation would have been required to fully account for the dramatic decreases observed, and this clearly was not observed. The current-voltage curves for both the first and second IPSC were linear, and there was no effect of voltage on the degree to which PPD occurred. This lack of a voltage-sensitive component of PPD suggests that desensitization of the postsynaptic $\mathrm{GABA}_{\mathrm{A}}$ receptor may not be involved in the decrease observed. Depolarization has been shown to slow the rate of desensitization (Frosch et al., 1992; Oh and Dichter, 1992), and had desensitization been the underlying mechanism of PPD, the degree to which it was observed would have been greatly attenuated at depolarized potentials.

Although the above experiment ruled out some possible postsynaptic mechanisms of PPD in this system, other postsynaptic mechanisms, such as co-release of neuromodulators of the postsynaptic membrane, could not necessarily be eliminated by these experiments. Therefore, to test directly for the location of the mechanism of PPD, the effect of IPSCs on the amplitudes of mIPSCs was determined. The ability to resolve minis arising from the majority of activated postsynaptic receptors is a powerful technique for assessing changes in synaptic efficacy. Many previous studies have shown that any observed change in the amplitude of miniature currents is the result of postsynaptic modifications (del Castillo and Katz, 1954; Van Der Kloot, 1991; Malgaroli and Tsien, 1992; Manabe et al., 1992; Otis and Mody, 1992). In the present experiments, there was no change in either the frequency or the amplitude of minis that occurred soon after an IPSC. If a postsynaptic modification was underlying the PPD, then the amplitude of the miniature currents should have been greatly depressed, and this was not observed. Moreover, it was possible to resolve changes in miniature amplitude following a change in the chloride driving force as a result of changing the membrane potential; therefore, the level of resolution in the recordings was not a limiting factor in detecting changes in miniature current amplitudes.

The results of the miniature current experiments directly demonstrate that the robust PPD between hippocampal neurons in low-density cultures is due to a presynaptic mechanism. We propose that, for this culture system, a decrease in the amount of neurotransmitter released following the second IPSC of a pair underlies the dramatic plasticity observed and that autoinhibition via $\mathrm{GABA}_{\mathrm{B}}$ receptors is not involved. This conclusion was supported by the observation that three $G \wedge B \Lambda_{B}$ receptor antagonists (CGP-35348, saclofen, and phaclofen) were unable to prevent PPD. Under the recording conditions used in these experiments, the probability of neurotransmitter release is relatively high for a single evoked IPSC, as evidenced by the relative lack of failures. Following the first IPSC, the quantal content decreases for several seconds. This hypothesis is supported by the finding that any manipulation that lowers the probability of release during the first action potential (e.g., low calcium or baclofen) will prevent the development of the robust PPD uniformly seen in these cells under baseline conditions.

The present experiments may explain the results of PPD studies in hippocampal brain slice by Davies et al. (1990) and Mott et al. (1993). Those researchers interpreted the ability of saclofen to block PPD as evidence that activation of presynaptic GABA $_{B}$ receptors was the mechanism of PPD. However, in those experiments, high concentrations of saclofen greatly reduced transmitter release following the first stimulus of a pair, and it was necessary to increase greatly the amplitude of the stimulation to obtain initial IPSCs of comparable amplitude to IPSCs in the pre-saclofen condition. Therefore, in those studies, as demonstrated here, saclofen diminished the likelihood of PPD by decreasing the quantal content for both IPSCs. In the present experiments, saclofen $(100 \mu \mathrm{M})$ had no effect on the presynaptic action potential measured at the soma, but did reduce the amplitude of the evoked IPSC, suggesting that saclofen at high concentrations $(>100 \mu \mathrm{M})$ acts as a partial $\mathrm{GABA}_{\mathrm{B}}$ agonist rather than as a specific antagonist. If it were acting as a specific antagonist, it would be expected that the IPSC amplitude in the presence of saclofen, would be either unchanged, or perhaps a bit greater, as saclofen would antagonize the effects of any endogenous extracellular GABA that might be tonically activating presynaptic $\mathrm{IABA}_{\mathrm{B}}$ receptors. Therefore, in the experiments of Davies et al. (1990) and Mott et al. (1993), saclofen, at the concentrations used (up to $1.0 \mathrm{~mm}$ ), was acting as a partial agonist at the presynaptic $\mathrm{GABA}_{\mathrm{B}}$ receptor and, just as baclofen has been reported to do, saclofen greatly reduced the probability of GABA release, and reduced the degree of PPD observed.

At the present time, the precise mechanism through which neurotransmitter release is reduced for up to $4 \mathrm{sec}$ is not understood. However, the results of these frequency-dependent experiments are very similar to what has been observed at the squid giant synapse, where synaptic depression occurs in the presence of high concentrations of calcium, and augmentation occurs when the extracellular concentration of calcium is lowered (Charlton et al., 1982; Swandulla et al., 1991). Before the mechanism underlying depression at central ncurons may bc revealed, a more detailed understanding of the entire secretion process in central neurons will need to be elucidated. However, depression at inhibitory synapses may be a necessary mechanism to allow long-term enhancement of excitatory synaptic currents to occur during learning. In addition, disinhibition may play a critical role in the development of excess neuronal excitability that is most significantly, and counterproductively, expressed as an epileptic seizure (Dichter and Ayala, 1987; Dichter, 1988). Future studies can now be directed to defining the biochemical and molecular mechanisms underlying this important presynaptic form of synaptic plasticity in the mammalian CNS.

\section{References}

Alger BE (1991) Gating of GABAergic inhibition in hippocampal pyramidal cells. Ann NY Acad Sci 627:249-263.

Ben-Ari Y, Krnjevic K, Reinhardt W (1979) Hippocampal seizures and failure of inhibition. Can J Physiol Pharmacol 57:1462-1466.

Bittiger H, Froestl W, Hall R, Karlsson G, Klebs K, Olpe H-R, Pozza MF, Steinmann MW, van Riezen H (1990) Biochemistry, electrophysiology and pharmacology of a new GABA-B antagonist: CGP 35348. In: GABA-B receptors in mammalian function (Bowery NG, Bittiger H, Olpe H-R, eds), pp 47-60. Chichester: Wiley. 
Bormann J (1988) Electrophysiology of $\mathrm{GABA}_{\mathrm{A}}$ and $\mathrm{GABA}_{\mathrm{B}}$ receptor subtypes. Trends Neurosci 11:112-116.

Buchhalter J, Dichter M (1991) Electrophysiological comparison of pyramidal and stellate, non-pyramidal neurons in dissociated hippocampal cell cultures of rat hippocampus. Brain Res Bull 26:333338.

Charlton MP, Smith SJ, Zucker RS (1982) Role of presynaptic calcium ions and channels in synaptic facilitation and depression at the squid giant synapse. J Physiol (Lond) 323:173-193.

Davies CH, Davies SN, Collingridge GL (1990) Paired-pulse depression of monosynaptic GABA-mediated inhibitory postsynaptic responses in rat hippocampus. J Physiol (Lond) 424:513-531.

Davies CH, Starkey SJ, Pozza MF, Collingridge GL (1991) GABA $_{в}$ autoreceptors regulate the induction of LTP. Nature 349:609-611.

Deisz RA, Prince DA (1989) Frequency-dependent depression of inhibition in guinea-pig neocortex in vitro by $\mathrm{GABA}_{\mathrm{B}}$ receptor feedback on GABA release. J Physiol (Lond) 412:513-541.

del Castillo J, Katz B (1954) Statistical factors involved in neuromuscular facilitation and depression. J Physiol (Lond) 124:574-585.

Delfs J, Dichter M (1983) Effects of somatostatin on cortical neurons in culture. J Neurosci 3:1176-1188.

Dichter MA (1988) Modulation of inhibition and the transition to seizures. In: Mechanisms of epileptogenesis. The transition to seizure (Dichter MA, ed), pp 169-182. New York: Plenum.

Dichter MA, Ayala GF (1987) Cellular mechanisms of epilepsy: a status report. Science 237:157-164.

Dolphin AC, Scott RH (1987) Calcium channel currents and their inhibition by $(-)$-baclofen in rat sensory neurones: modulation by guanine nucleotides. J Physiol (Lond) 386:1-17.

Dutar P, Nicoll RA (1988) Pre- and post-synaptic GABA $A_{B}$ receptors in the hippocampus have different pharmacological properties. Neuron 1:585-591.

Edwards FA, Konnerth A, Sakmann B (1990) Quantal analysis of inhibitory synaptic transmission in the dentate gyrus of rat hippocampal slices: a patch-clamp study. J Physiol (Lond) 430:213-249.

Forsythe ID, Clements JD (1990) Presynaptic glutamate receptors depress excitatory monosynaptic transmission between mouse hippocampal neurones. J Physiol (Lond) 429:1-16.

Frosch M, Lipton S, Dichter M (1992) Desensitization of GABAactivated currents and channels in cultured cortical neurons. J Neurosci 12:3042-3053.

Gahwiler BH, Brown DA (1985) GABA $_{\mathrm{B}}$-receptor-activated $\mathrm{K}^{+}$current in voltagc-clamped $C A 3$ pyramidal cclls in hippocampal cultures. Proc Natl Acad Sci USA 82:1558-1562.

Greengard P, Valtorta F, Czernik AJ, Benfenati F (1993) Synaptic vesicle phosphoproteins and regulation of synaptic function. Science 259:780-785.

Hamill OP, Marty A, Neher E, Sakmann B, Sigworth FJ (1981) Improved patch-clamp techniques for high-resolution current recording from cells and cell-free membrane patches. Pfluegers Arch 391:85100.

Harrison NL (1990) On the presynaptic action of baclofen at inhibitory synapses between cultured rat hippocampal neurones. J Physiol (Lond) 422:433-446.

Harrison NL, Lange GD, Barker JL (1988) (-)-Baclofen activates presynaptic $\mathrm{GABA}_{B}$ receptors on $\mathrm{GABAergic}$ inhibitory neurons from embryonic rat hippocampus. Neurosci Lett 85:105-109.

Korn H, Faber DS (1987) Regulation and significance of probabilistic release mechanisms at central synapses. In: Synaptic function (Edelman GM, Gall WE, Cowan WM, eds), pp 57-108. New York: Wiley.

Korn H, Faber DS (1991) Quantal analysis and synaptic efficacy in the CNS. Trends Neurosci 14:439-445.

Korn H, Faber DS, Burnod Y, Triller A (1984) Regulation of efficacy at central synapses. J Neurosci 4:125-130.

Llano I, Marty A, Armstrong CM, Konnerth A (1991) Synaptic- and agonist-induced excitatory currents of Purkinje cells in rat cerebellar slices. J Physiol (Lond) 434:183-213.

Malgaroli A, Tsien RW (1992) Glutamate-induced long-term potentiation of the frequency of miniature synaptic currents in cultured hippocampal neurons. Nature 357:134-139.

Manabe T, Renner P, Nicoll RA (1992) Postsynaptic contribution to long-term potentiation revealed by the analysis of miniature synaptic currents. Nature 355:50-55.

Mattson MP, Kater SB (1989) Development and selective neurodegeneration in cell cultures from different hippocampal regions. Brain Res 490:110-125.

McCarren M, Alger B (1985) Use-dependent depression of IPSPs in rat hippocampal pyramidal cells in vitro. J Neurophysiol 53:557-571.

Mott DD, Xie C-W, Wilson WA, Swartzwelder HS, Lewis DV (1993) $\mathrm{GABA}_{\mathrm{B}}$ autoreceptors mediate activity-dependent disinhibition and enhance signal transmission in the dentate gyrus. J Neurophysiol 69: 674-691.

Oh D-J, Dichter MA (1992) Desensitization of GABA-induced currents in cultured rat hippocampal neurons. Neuroscience 49:571-576.

Olpe H-R, Karlsson G, Pozza MF, Brugger F, Steinmann M, van Riezen H, Fagg G, Hall RG, Froestl W, Bittiger $H$ (1990) CGP 35348: a centrally active blocker of GABA-B receptors. Eur J Pharmacol 187 : 27-38.

Otis TS, Mody I (1992) Differential activation of GABA and GABA receptors by spontaneously released transmitter. J Neurophysiol 67 : 227-235.

Redman S (1990) Quantal analysis of synaptic potentials in neurons of the central nervous system. Physiol Rev 70:165-198.

Ropert N, Miles R, Korn H (1990) Characteristics of miniature inhibitory postsynaptic currents in CA1 pyramidal neurones of rat hippocampus. J Physiol (Lond) 428:707-722.

Scanziani M, Capogna M, Gahwiler BH, Thompson SM (1992) Presynaptic inhibition of miniature excitatory synaptic currents by baclofen and adenosine in the hippocampus. Neuron 9:919-927.

Scharfman IIE, Schwartzkroin PA(1989) Selective depression or GABAmediated IPSPs by somatostatin in area CA1 of rabbit hippocampal slices. Brain Res 493:205-211.

Scholz KP, Miller RJ (199I) GABA B receptor-mediated inhibition of $\mathrm{Ca}^{2+}$ currents and synaptic transmission in cultured rat hippocampal neurones. J Physiol (Lond) 444:669-686.

Swandulla D, Hans M, Zipser K, Augustine GJ (1991) Role of residual calcium in synaptic depression and posttetanic potentiation: fast and slow calcium signaling in nerve terminals. Neuron 7:915-926.

Thies RE (1965) Neuromuscular depression and the apparent depletion of transmitter in mammalian muscle. J Neurophysiol 28:427442.

Thompson SM, Gahwiler BH (1989a) Activity-dependent disinhibition. I. Repetitive stimulation reduces ipsp driving force and conductance in hippocampus in vitro. J Neurophysiol 61:501-511.

Thompson SM, Gahwiler BH (1989b) Activity-dependent disinhibition. II. Effects of extracellular potassium, furosemide, and membrane potential on $\mathrm{Ecl}$ in hippocampal CA3 neurons. J Neurophysiol 61: $512-523$.

Thompson SM, Gahwiler BH (1989c) Activity-dependent disinhibition. III. Desensitization and GABAb receptor-mediated presynaptic inhibition in the hippocampus in vitro. J Neurophysiol 61:524-533.

Thompson SM, Gahwiler BH (1992) Comparison of the actions of baclofen at pre- and postsynaptic receptors in the rat hippocampus in vitro. J Physiol (Lond) 451:329-345.

Van Der Kloot W (1991) The regulation of quantal size. Prog Neurobiol 36:93-130.

Vautrin J, Schaffner AE, Barker JL (1992) Two classes of spontaneous GABA-mediated miniature synaptic currents in cultured rat hippocampal neurons. Neurosci Lett 138:67-71.

Vincent P, Armstrong CM, Marty A (1992) Inhibitory synaptic currents in rat cerebellar purkinje cells: modulation by postsynaptic depolarization. J Physiol 456:453-471.

Wilcox KS, Dichter MA (1991) Properties of inhibitory and excitatory miniature currents in hippocampal neurons maintained in low density culture. Soc Neurosci Abstr 17:1155.

Yoon K-W, Rothman SM (1991) The modulation of rat hippocampal synaptic conductances by baclofen and gamma-aminobutyric acid. J Physiol (Lond) 442:377-390.

Zucker RS (1988) Frequency dependent changes in excitatory synaptic efficacy. In: Mechanisms of epileptogenesis. The transition to seizure (Dichter MA, ed), pp 153-168. New York: Plenum. 